\title{
Damian Wolski*
}

\section{EARLY BRONZE AGE FLINT MATERIALS FROM LESSER POLAND - THEIR RESEARCH PROBLEMS AND SUGGESTIONS FOR THEIR INTERPRETATION}

\begin{abstract}
Wolski D. 20013. Early Bronze Age flint materials from Lesser Poland - their research problems and suggestions for their interpretation. Sprawozdania Archeologiczne 65, 145-193.

The present paper summarizes the state of research of the flint technology belonging to the Early Bronze Age in the Lesser Poland loessic areas. With the analyses of representative materials from the most important settlements, cemeteries and mines, an attempt has been made to verify the current identification criteria for the flint artefacts of the concerned period.

The observations allow for the construction of a theoretical model which connects to the manufacturing of bifacial daggers and sickles as well as with the spezialization of their production. The fact that these tools were made continuously for several centuries, may be attributed to some special social mechanisms in which technology teachers played an important role. This model was based on selected conceptions of social psychology.
\end{abstract}

Key words: flint technology, Early Bronze Age, Mierzanowice culture, social psychology Received: 2.11.2011; Revised: 10.08.2012; Accepted: 28.06.2013

\section{INTRODUCTION}

Despite a significant increase in interest in the post-Neolithic flint knapping in recent years (e.g. Lech 1997, 237-249; Kopacz 2001; Libera 2001), the current state of knowledge on the subject cannot be regarded as entirely satisfactory. Still, there are new questions

*Institute of Archaeology, Rzeszów University, Hoffmanowej st. 8, 35-016 Rzeszów, Poland; dmn.wolski@ gmail.com 
addressing the hypotheses of its functioning which has been written about in literature for several decades. It is fundamentally necessary to review the current arrangements, their verification and may be to propose other theoretical solutions.

What is especially valuable to consider is the phenomena, referred to as "the technological breakthrough" in the Neolithic and Bronze Age (Kopacz, Valde-Nowak 1987). Flint materials of that period are strongly differentiated morphologically. A major problem is created by the inhomogeneous inventories. Settlement artefacts coming from different periods are often mixed together. The Early Bronze Age chronology of the sepulchral sites is unquestionable, even despite the presence of the graves redeposits (among others Kadrow, Machnikowie 1992; Baczyńska 1993). However, there are only a small number of Early Bronze Age cemeteries. Moreover, it is also believed that the Early Bronze Age community (as opposed to the Neolithic) was producing flint tools using local raw materials. The exceptions are technologically advanced bifacial forms, especially considering daggers and sickles (Kadrow 1995b, 241-245). Although these artefacts are mostly finds deprived of an archaeological context (Libera 2001, 78, 92), they can still showcase the advanced skills of their manufacturers (Kopacz, Valde-Nowak 1987, 78). Raw materials, from which they were made, came from distant deposits even as far as hundreds of kilometres. Moreover, determining the chronological-cultural affiliations of the mining sites always poses a number of difficulties. In fact there are no appropriate methods of dating such complexes (Budziszewski 1998, 290).

This argument points to the difficulties in the correct identification of flint finds coming from the Early Bronze Age. That is why this problem needs more attention, and it will also be the topic of this article. Moreover, the aim of this work is to propose a theoretical concept relating to the selected elements of the Early Bronze Age flint knapping in Lesser Poland. At the same time, in order to give the article an interdisciplinary approach, the author has tried to present the consideration of a vision of man and society from the perspective of social psychology.

\section{THE SPATIAL EXTENT AND THEORETICAL ASSUMPTIONS}

The spatial extent of consideration is limited to the area of south-east Poland, mainly loess zone. It includes in particular the Lesser Poland Upland, Lublin-Lvov Upland and the western part of the Volhynia-Podolye Upland (Kondracki 2002). This area corresponds to a large extent the historical region of Lesser Poland. With reference to the proper reception of the presented content, it should be noted that the interest of our consideration will mainly cover the community of the Mierzanowice culture. Thus, the issues regarding the Strzyżów culture will be emphasized only partially or completely ignored.

To validate the thesis posed later in the work, I would like to draw attention to the elements that determine the shape of the flint knapping. I assume that the nature of flint 
knapping during a particular period of time and in a particular area is a result of the intensity of each of the following factors. The first one is a need, however, not only in terms of economic possibility of the use of specific tools. This term will also include a demand for prestige products (Banning 2000, 141). The second element is the qualification of flint knappers. It should be understood as a physical human motor skill, his abilities, experience and knowledge. These elements are an expression of possibilities and efficiency (Pelegrin 1990, 116-125; Banning 2000, 141). What is more, important factors determining the shape of flint knapping may also be conditioned by local raw materials (Apel 2001, 30), and cultural traditions.

When using the term "tool" in the article, I mean its morphology. Thus, I am not referring to the usability features of products, unless I write it clearly in the text. As for the flint knapping studies I do not see the terms "technology" and "technique" as synonyms. "Technology" is a broad thinking concept that leads to a particular method of reducing a block of flint. It will include both knowledge and experience in all activities related to the theory and practice of flint knapping, whereas "technique" will refer to specific methods of flaking (e.g., hammer flaking, punch flaking or pressure flaking) (see Andrefsky 1998, 11-12).

\section{HISTORY AND STATE OF THE RESEARCH}

A detailed history of the research on flint materials coming from the Early Bronze Age in Lesser Poland has already been presented in the literature (Kopacz, Valde-Nowak 1987, 58-62). Notes considering the history of the knowledge development about flint knapping of that period, including some regions of Central Europe, has been presented by Jażdżewski (1981, 15-53) and Kopacz (2001, 37-38). Other researchers have demonstrated the state of the research on the clearly distinctive tool forms affiliated with the Early Bronze Age implements with bifacial surface flaking (Borkowski 1987; Bargieł, Libera 1997, 145-146; Borkowski, Kowalewski 1997, Libera 2001, 12-22, 46-50 ). Some significant studies have not appeared in print to this day. This includes a review of flint knapping covering the settlement region in Iwanowice (Kopacz 1978) and materials coming from the Early Bronze Age cemeteries of the Sandomierz Upland (Bąbel 1987). Two other important works were published in abridged form - in articles. They raised issues of technology and morphology of heart-shaped arrowheads (Borkowski 1987), and they presented a review of flint inventories coming from the turn of the Neolithic and Bronze Age in Środkowomatopolska (Mid-Lesser Poland) Upland (Budziszewski 1991). The work of a similar nature to the last mentioned work was published by Balcer in relation to the material of the upper part of the Wieprz River (1991; also Balcer et al. 2002).

Since the beginning of the twentieth-century the researchers studying numerous finds attempted to systematize the knowledge concerning stone materials discovered, making suggestions on their chronology and cultural affiliation. The first attempts to differentiate 
the flint materials (of the Early Bronze Age provenience in the modern sense) as a separate category of artefacts dates back to the time before World War I and the activities undertaken by Kozłowski $(1913,1917)$. This researcher, studying archaeological excavations carried out in the area of Iwanowice, first drew attention to the specifics of the distinguishing materials found there, allotting them to the "Iwanowice industry" $(1913,40)$. The inventory of the mentioned unit then consisted of the mixed materials known today as the Neolithic and Early Bronze Age with the predominant numbers of the last mentioned period. Subsequent interpretations of the same scholar defined the Early Bronze Age, Lesser Poland flint material as belonging to the "Microlithic culture" which was differentiated that time (Kozłowski 1923, 160), and then, after the modification, to "Microlithic Neolithic culture" (Kozłowski 1924, 24) and the "Nadbużanski industry/culture" (Kozłowski 1924, 85-90).

Some extremely important studies concerning the settlement and cemetery in Mierzanowice were conducted in 1936-1938. Numerous stone artefacts were uncovered in the course of the excavations (Salewicz 1937). Almost simultaneously excavations were conducted in Volyn and Strzyżów, where it was discovered that several other sites contained Early Bronze Age materials - among others Torczyn (Fitzke 1938; 1975) and Sapanów (K. J. 1936; Podkowińska 1936; 1960).

The studies carried out in the days before and after the war made it possible to classify the implements of "macrolithic" nature and bifacially worked, including bifacial axes, as affiliating to the cultures of the turn of Neolithic and Bronze Age in Lesser Poland (see Salewicz 1937, 58-59; Kopacz, Valde-Nowak 1987, 60).

Flake tools came to be seen as implements specific to this period (e.g. Machnik 1967). In this way, it outlined the bipolar development of flint knapping at the turn of the ages - on the one hand it contained technologically complex bifacial forms with retouched surfaces, and on the other hand there were common flakes, often deprived of intentional retouches (see Balcer 1971, 63-68).

Valuable to the expansion of knowledge of Early Bronze Age flint knapping were excavations carried out at the settlement complex in Iwanowice (Machnikowie 1973). Numerous stone implements provided a more complete picture of this kind of manufacture. Initial development of the materials was made by Kopacz (1976), who described at the same time the distinctive and essential features of the Early Bronze Age flint knapping in Lesser Poland. Moreover, flint artefacts from the settlement in Mierzanowice were studied (Balcer 1977).

It is worth mentioning that other materials, nowadays known from the Early Bronze Age due to their specificity, were sometimes associated with the Older Stone Age (Schild 1971, 42-48). Sometimes the researchers did not undertake the chronology determination of such inventories at all (Chmielewska 1973). It applies to the uncovered mining sites: Polany II and Polany Kolonie II. Verification of these views took place in the 70 s of the twentieth century (Schild et al. 1977; see the comments Budziszewski 2008, 36-37). 
The change of the nature of flint working, which occurred at the turn of the periods, has received the name "technological-implemental revolution" (Schild et al., 1977, 96, see also Lech 1982/1983, 53). The typical features of this phenomenon were: the "macrolitization" of some tools, the disappearance of blade technology, intensification of core technology and surface knapping of tools (Kopacz, Valde-Nowak 1987, 79).

An important place in the history of research regarding stone remains in Lesser Poland was taken by the scholars Kopacz and Valde-Nowak, who made a summary analysis of the Early Bronze Age flint working in the region, contrasting it to the Neolithic inventories (Kopacz, Valde-Nowak 1987). The researchers referred mainly to the economy of raw materials and tools, synthesizing existing knowledge, as well as introducing new and original theses. They considered the Early Bronze Age communities as economically self-sufficient in terms of raw materials (Kopacz, Valde-Nowak 1987, 75). They introduced to the literature, the term "conventional tools", denoting high-quality bifacial tool forms, characteristic of the Early Bronze Age (Kopacz, Valde-Nowak 1987, 78). They included generally daggers, sickles, arrowheads, and axes. What is more, these researchers made geographical distinctions of inventories. They noted that the complexes coming from the Lesser Poland loess, characterized by the very high economic potential for agricultural societies, bore the most features of "technological-implemental revolution". The presence (or not) of the "conventional tools" in the particular region of Lesser Poland was explained by the quality of available raw materials, which was plentiful in Volhynia (Volhynian flint) and Sandomierz Land (Ożarów flint and some types of chocolate flint) (Kopacz, Valde-Nowak 1987, 79). In addition, it was noticed that a specific canon of the manufacturing process, having its origin mainly in the studies of Palaeolithic complexes, implementing the model of flint lump reduction in the direction of the desired tool, underwent a major change in the Late Neolithic and Early Bronze Age. It is evidenced by a large number of irregular flake forms, often unretouched, which could have served their utility functions (see also Lech 1997, 237249). According to the authors of the study "[...] an essential condition to obtain success in research examining flint working changes which took place at the turn of periods is not built upon a detailed, considered universally list of features or types of artefacts, but it is necessary to understand a new concept of transforming raw materials into tools, the concept which was different from the previous periods" (Kopacz, Valde-Nowak 1987, 82). The terms debris, core or tool in the light of Early Bronze Age inventories have been considered as very ambiguous (Kopacz, Valde-Nowak 1987, 82). The research conducted by Kopacz and Valde-Nowak is crucial, because the scholars abandoned classical "enumeration" of typical forms of artefacts and their description. They made an attempt to solve specific research questions about the economy and society.

An important direction of research concerned the recovery methods for obtaining raw flint materials by the Early Bronze Age communities. The researchers presented monographs referencing the following mining sites: Polany Kolonie II (Schild et al. 1977), Polany II (Chmielewska 1988), Wierzbica “Zele” (H. and J. Lech 1984), Tomaszów I (Schild 
et al. 1985) and the reserve "Krzemionki" (Borkowski et al. 1989). At the beginning of the 8 os of the twentieth century, Lech prepared a synthetic study which described the exploitation units (types of pits, shafts) of raw flint materials (1981, 20-33). A thorough review of flint mining materials and their classification as complexes of the Early Bronze Age was made by Budziszewski (1998). Next to the mining sites were also places of the manufacture of raw flint materials, where raw materials were flaked, producing numerous initially prepared forms of axes and bifacial sickles (among others. Schild et al. 1977, 103; Lech 1982/1983, 71-77; Budziszewski 1998, 286-298). In this perspective, the final stages of production might have been done in the home village of miners (Schild et al. 1977, 103). These studies often emphasized the aspects of the mining of the raw materials such as the use of shaft pits, collecting the material from the surface around the mine and the effectiveness of the work performed. Opinions of the researchers regarding the use of raw flint materials was summarised by Kadrow (1995a, 76-82). This scholar compiled together a bipolarity of flint working in Lesser Poland. The tendency of the Early Bronze Age population to produce "conventional tools" of high-quality flint was emphasised, originating from distant outcrops. This was contrasted with a simultaneous tendency of the same community to collect flint material from the nearby area (Kadrow 1995a, 76-82, see also Kadrow 1995b, 241-245).

Flint materials have become an increasingly important source of interpretation of the economy and its variability in the Early Bronze Age. This was noticed by Kadrow when presenting an example of a micro-region settlement in Iwanowice. The researcher regarded it as a typical settlement for the Early Bronze Age community from Lesser Poland in terms of raw material and the demand for tools (Kadrow 1995a, 80).

A separate issue concerns implements with two-sides for surface knapping. The occurrence of bifacial forms was noted in almost all Europe during the Early Bronze Age (see remarks van Gijn 1988, 2010, Lech 1997, 237-249; Apel 2001; Kopacz 2001; Libera 2001). With regards to the literature, there is a common consensus that these forms served a special role that went beyond the function of utility. (among others Kadrow 1995a, 80; Olausson 2000, 128; Apel 2001, 330). However, other studies confirm the utility function of those implements (Bąbel, Budziszewski 1978; Balcer, Schild 1978a; 1978b; 1980). Flint products have become a major cognitive material upon which it is possible to indicate power and prestige in societies of the Early Bronze Age (Kadrow 1995a, 93; 2001, 160-161; Olausson 2000, 128; Apel 2001, 330). Although the typical Mierzanowice community might have existed without these types of prestige items, these products may have been socially valued as an object of far-reaching exchange (Kadrow 1995a, 93). According to Kadrow, an exchange of this type "was probably institutional" and its mechanisms "influenced on the organization, stability and evolution of social macrostructures". In addition, exchange items as well as their mechanisms of circulation could be used to "maintain power and sustain an already possessed social prestige" (Kadrow 1995a, 93).

In recent years, the works concerning the Early Bronze Age flint knapping in Lesser Poland have had a typically cultural and historical character. A major role was played by 
a morphometric and evolutionary approach. These publications focus on an extensive stylistic and typological analysis of the remains (Bargiel, Libera 1997; Borkowski, Kowalewski 1997; Libera 2001). Social and cultural phenomena are interpreted as a result of reaching Lesser Poland some elements of which came from the highly developed material culture of the Carpathian Basin (Kopacz 2001).

\section{CHARACTERISTICS OF SOURCES}

\section{a. Cemeteries}

Szarbia is the first distinguished sepulchral site (Baczyńska 1993). The cemetery should be combined with two chronological phases of the Mierzanowice culture - classical and late (Baczyńska 1993, 7). There were 79 recorded flint items - 50 waste fragments, 28 tools and 1 bipolar core (Baczyńska 1993, 27). A high disturbance of the stratigraphy was noted, therefore the materials may be considered to be Neolithic redeposits. This circumstance allowed the researchers to consider some of the grave goods - heart-shaped arrowheads (19 units) and two other tools - a part of a piercer and a knife of the Early Bronze Age. The vast majority of these products were made of Jurassic flint (Baczyńska 1993, 27).

Another cemetery that was very rich was discovered in Mierzanowice (Salewicz 1937). The study revealed many valuable flint remains. Unfortunately, a substantial number of them came from layers damaged by agricultural activities. There were more than 300 heart-shaped arrowheads discovered at the site - (Salewicz 1937, 46). Of the finds from the excavated graves in Mierzanowice, it is worth noting the significant amount of sickles (a total of 28 items) (Salewicz 1937, 50, 53, 56, 57) several knives (Salewicz 1937, fig. 1213: 13a; fig. 17: d) and an axe with a lenticular cross section (Salewicz 1937, fig. 17: e, fig. 20: d, 24 a, c, d). With regards to the raw materials, Ożarów flint was predominant (Salewicz 1937,50$)$.

It is worth mentioning some of the grave sites, which provided items of daggers (see Bargiel, Libera 2005). Firstly, it is necessary to mention site 3 and 4 in Czerniczyn where the researchers uncovered several such implements with varying shapes (Libera 2001, 77). Daggers, regarding the sepulchral context, are also known from several sites among others as Siekierzyńce, Sitno, Strzyżów, Miernów (Libera 2001, 77), Wojciechowice (Kadrow, Machnik 1997, 85), Złota (Libera 2001, 82) and Raciborowice-Kolonia, site II - (Libera 2001, 81). These artefacts generally date to the Early Bronze Age (see Budziszewski 1991, 196), although some of them tend to be identified with the Strzyżów culture. The context of the dagger known from grave 55 in Wojciechowice suggests that the production of these tools took place up to the late phase of the Mierzanowice culture (Libera 2001, 81).

In addition to the sickles being widely represented in the Mierzanowice cemetery, these remains are also known on a smaller scale in several other sepulchral sites. They were 
discovered among other things at: Złota "Nad Wawrem”, Wojciechowicach site 1, Orliska Sokolnickie site 1 and also in Trześń. The sickles uncovered in these cemeteries were mainly made of Ożarów flint, a few of chocolate and Świeciechów flint (Libera 2001, 92-93).

It should be noted that there is a coexistence of sickles with copper products and a distinctive pottery in the graves coming from the cemeteries in Mierzanowice and Złota. This fact lets us date them to the late phase of the Mierzanowice culture. This chronology may also be indicated on the basis of their obvious absence in the earlier stages of development of this culture (see Kadrow, Machnik 1997, 83; Kadrow 2000, 142, Libera 2001, 93-94).

\section{b. Settlements}

With regard to the discussed issue, a crucial importance is highlighted by the settlement complex at Babia Góra in Iwanowice. The Early Bronze Age flint products found on this site were studied in details by Kopacz (1978). The vast majority of the material comes from the fills of features defined on the basis of pottery as belonging to the Mierzanowice culture (Kopacz, 1976, 88-90). More than 30,000 artefacts were identified, most of which were made of the Jurassic flint variety B2. The inventory also included the implements made of other local siliceous rocks (cherts). Occasionally there were chocolate flint products, obsidian as well as Volyn and striped flint artifacts (Kopacz 1978 for Valde-Nowak 1987, 63). A full inventory structure has been presented in a separate article - but it is a small indicator of the entire content of Iwanowice (Kopacz 1976). Kopacz defined the site as a typical flint workshop indicating a very high percentage of flakes and waste products (over 95\%) (Kopacz, 1976, 104). Raw materials were described as poor quality and core forms as negligent (Kopacz, 1976, 91-92). Attention was drawn to the lack of possibility to use on a large scale any complex technology, such as the blade reduction of a flint block (Kopacz, 1976, 89-90). As for the core tools, the dihedral, narrow butted axes were identified, lenticular (17 finished products - polished and 9 unfinished ones). They were made mostly from a poorly silicification of flint (petrosilex), which is often close to limestone in terms of the appearance (Kopacz, 1976, 96-97). The author of the study indicates the presence of a significant number of scrapers and forms a typology similar to that of the Middle Palaeolithic (knife- and backed-shaped forms). Other types of products played a marginal role, and perhaps they were a culturally extraneous admixture (Kopacz, 1976, 97-99). The presented overview of the materials can be expanded only by a small amount of heartshaped arrowheads found outside the settlement features (Kopacz, Valde-Nowak 1987, 63). In addition, it is worth noting the presence of a dagger discovered in pit No. 83 (Kadrow, Machnik 1997, 67-68).

Special attention should be paid to the multiphase settlement in Mierzanowice of the Mierzanowice culture from where a rich collection of flint was found. The author of this research is Balcer (1977). The inventory included about 1,200 remains made primarily from striped flint (65.4\%), but also chocolate (16.4\%) and Świeciechów (9.7\%) flint were recorded. Poorly represented were Ożarów, Baltic and Volyn flint (Balcer 1977, 193). Flake 
reduction of a flint block appears to dominate in terms of technology. Blade and bipolar technology are rather poorly represented in the inventory (Balcer 1977, 203). Waste products and preforms dominate the flint artefacts there (91\%) (Balcer 1977, 197). The main and most characteristic group coming from the site is a collection of initial and semifinished dihedral axes (67 items) (Balcer 1977, 198), as well as the products referred to as side-scrapers and bifacial knife-shaped forms (Balcer 1977, 199-200). What is more, it was noted the insignificant number of remains characterized by bifacial surface retouching (two arrowheads and one dagger) (Balcer 1977, 200). The Mierzanowice features also revealed evidence of Neolithic redeposits in a form of tetrahedral axes of the Globular Amphora culture (Balcer 1977, 193). In the literature, there are critical voices questioning the recognition of the materials from the settlement in Mierzanowice as a reliable source of knowledge - among other things because of the mixed Early Bronze Age and Neolithic artefacts (Budziszewski, 1991, 196). However, there is no doubt that the multi-phase use of the Mierzanowice settlement with its large number of artefacts provides a broad view of the flint manufacture used by the discussed community.

Another distinguished settlement site is located in Opatkowice. Flint materials from this site have been studied by Valde-Nowak (2000). It is worth mentioning the particularly rich complexity of pit No. 4, affiliated to the Early Bronze Age (Valde-Nowak 200o, 305). The author points out the workshop part of the complex. In this area he has differentiated hammer stones, cores and flakes, with a small percentage of the latter (Valde-Nowak 2000, 317). Considering the inventory, there are no such forms as daggers, sickles, axes or arrowheads. On the other hand, there is a high rate of knife-shaped and backed forms (Valde-Nowak 2000, 317) as well as bipolar ones (Valde-Nowak 2000, 311). Moreover, atypical forms have been identified - trapezoidal segments with saw-shaped edges, known from the Únĕtice and Otomani cultures (Valde-Nowak 2000, 318).

\section{c. Flint exploitation sites}

Materials originating from the mining sites require a separate comment. The first distinguished set of flint artefacts comes from the site "Za Garncarzami" in the area of Ożarów. It consisted of 4,200 items and contained 21 core forms. It was possible to isolate among them a mattock, a bipolar core, 5 side-scrapers, 2 cores, 3 amorphous core forms, 9 abandoned forms or fragments of initially worked forms of large bifacial tools (4 of them are associated with the production of sickle-shaped knives and two axes. Some core forms show signs of overheating (Budziszewski, 1998, 291). The second set from that site contained 2,300 flint artefacts. 14 core forms have been distinguished ( 2 cores, 8 abandoned forms or fragments of initially worked forms of large bifacial tools, including two sickleshaped knives) (Budziszewski 1998, 291).

One of the assemblages of chocolate flint by the Kamienna River "Wzgórze Kruk" (Budziszewski 1987) has also provided interesting finds. Flint workshops have been discovered associated with the production of amorphous flakes from wide striking surface 
cores used without a previous preparation, and in the final stages used in bipolar technique. In these workshops the presence of relatively numerous (0.5-1\%) artefacts made of Ożarów flint have been revealed - including an initial fragment of a sickle-shaped knife (Budziszewski 1987 for Budziszewski 1998, 295-296). This data allows us to combine the site with that of the Early Bronze Age.

Few abandoned fragments of initial forms of daggers are known from sites "Polany Kolonia II" (Schild et al. 1977), "Polany II" (Chmielewska 1973), sickle-shaped knives from "Polany Kolonia II" (Schild et al. 1977), "Polany II" (Chmielewska 1988), "Nowy Rachów" (Bargiel, Libera 1996), and dihedral axes from the sites "Polany II" (Chmielewska 1973), "Polany Kolonia II" (Schild et al. 1977), "Zele" (Młynarczyk 1983), "Nowy Rachów “ (Bargieł, Libera 1996). These objects are usually only surface finds without an archaeological context. As for the briefly described mining sites the following flint was exploited: chocolate, Świeciechów/Gościeradów, striped and Ożarów (Budziszewski, 1998, 288).

Interesting comments referring to how raw materials were obtained for the production of heart-shaped arrowheads have been provided by Budziszewski (1991; 2008, 38-39). It turns out that the most numerous finds in the area of exploitation of chocolate flint are flake forms. Due to their metric characteristics they could not be a productive material of large bifacial tools. The preparation of these flakes can be combined with the needs of the Early Bronze Age communities on high quality blanks, which were shaped into arrowheads (see Budziszewski 2008, 38-39, 93).

\section{d. Stray finds}

With regard to Lesser Poland, a series of daggers and sickles has been discovered without archaeological context. They represent 90\% of the currently known forms (Libera 2001, 78, 92). Tools with bifacial knapping discovered in the basin of the San River have been catalogued by Libera. There are more than11o listed daggers and sickles (Libera 2010, 21-27).

\section{THE MAIN FEATURES OF THE EARLY BRONZE AGE FLINT WORKING IN LESSER POLAND}

In light of the above sources, it is possible to present the basic features of the Early Bronze Age flint technology regarding the present geographical area. These characteristics include the distribution of the raw material economy, the tool structure and applied technologies and techniques.

a. Economy of raw materials

Raw materials generally came from the surrounding areas where possible. The conducted studies clearly show that the nature of the mining exploitation in the Early Bronze 


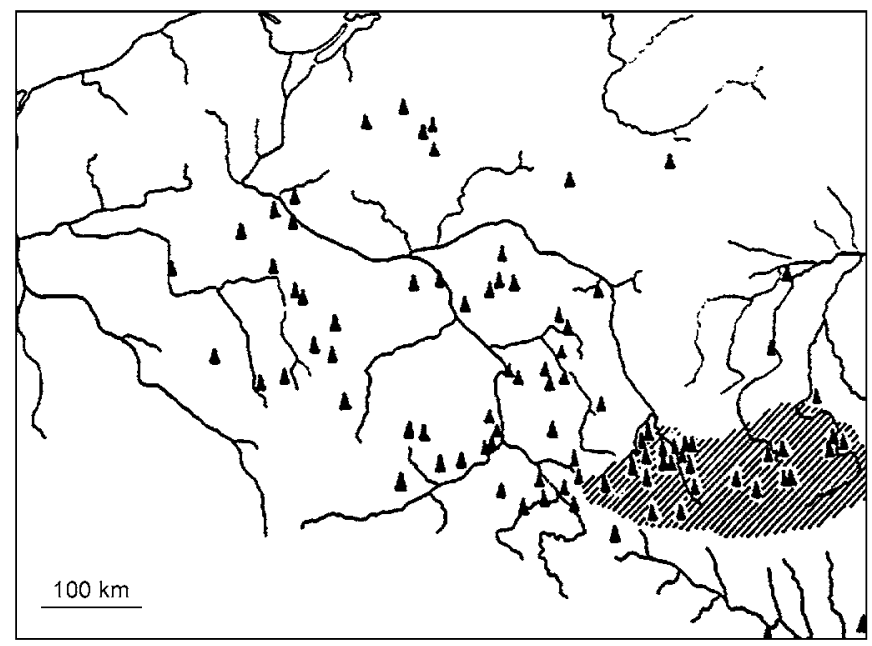

Fig. 1. The occurrence of daggers made of Volhynian flint, Key: black triangles - places of daggers finds, hatched area - territories where the daggers production took place (acc. to Machnik 1978)

Ryc. 1. Występowanie płoszczy z krzemienia wołyńskiego, gdzie: czarne trójkąty - miejsca znalezisk płoszczy, obszar zakreskowany - tereny, na których skupiała się produkcja płoszczy (za J. Machnik 1978)

Age was quite different compared to earlier periods. The main strategy and aim of these communities in obtaining raw materials was not to improve mining techniques and reaching for deeper lumps of flint. Instead, they usually selected areas of optimal logistic solutions based on perfect identification of the easily available deposits (Budziszewski 1991, 197). Rocks coming from remote deposits played a minor role, if not marginal (see Kadrow 1995b, 241-245). It is also worth mentioning a significant role of locally available rocks with lower silica content and non-siliceous rocks (Kopacz, Valde-Nowak 1987, 76). Bifacial forms were manufactured only from high-quality raw materials - mainly of Volhynian flint, and to a lesser extent, from Jurassic, Świeciechów, chocolate and Ożarów raw materials (Libera 2001, 77-82, 92-95, see also Libera 2010, 4, 16). Sometimes a selection of raw materials took place, which considered the production of certain forms with bifacial knapping (see Budziszewski 1991, 195-196).

\section{b. Technology and technique}

It is possible to draw the conclusion that the artefacts were implemented by means of different technologies. Regarding the collected inventories, the researchers noticed the presence of both flake and core forms (Kopacz 2001, 39). In addition, it is believed that the degree of morphological identity of initial and waste forms is very high (see Kopacz, ValdeNowak 1987, 78). There was a high tendency to use flake cores (Fig. 3). The role of blade technology can be considered insignificant regarding the Early Bronze Age communities 


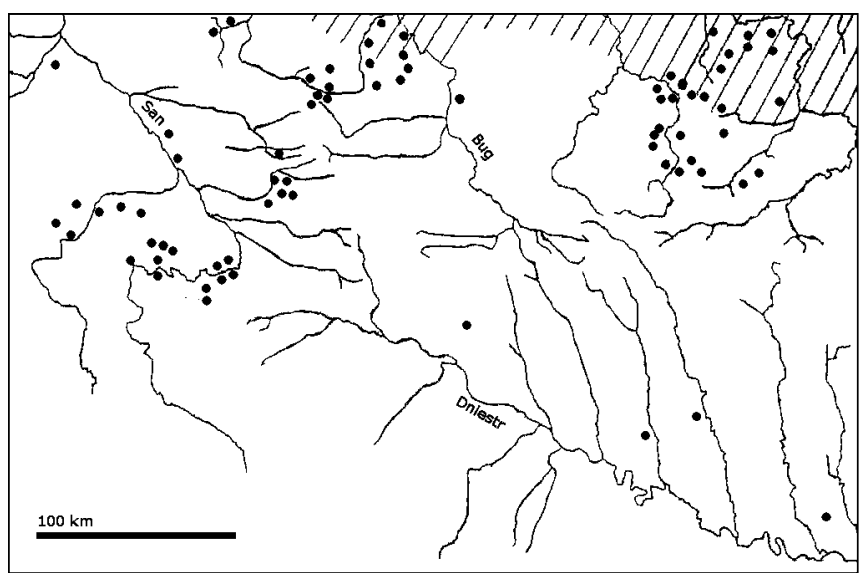

Fig. 2. The occurrence of sickles made of Volyn flint, Key: black spots - places of sickles finds, hatched area - the range of the Strzyżów culture (acc. to Kadrow 1995a)

Ryc. 2. Występowanie sierpów z krzemienia wołyńskiego, gdzie: czarne punkty - miejsca znalezisk sierpów, obszar zakreskowany — zasięg kultury strzyżowskiej (za S. Kadrow 1995a)

occupying loess territories of Lesser Poland (Lech 1982/1983, 53; Schild et al. 1985, 96; Kopacz, Valde-Nowak 1987, 79; Budziszewski 1991, 206). As for some inventories of the Early Bronze Age, it is worth mentioning a significant number of bipolar artefacts (among others Kraussowie 1971: fig. 7c; Valde-Nowak 2000, 311). These products may be linked not only with the desire to have efficient core knapping. They might have just played a function of universal tools (Budziszewski 1991, 201). Valde-Nowak constructs a more general hypothesis to disregard the standards (shape, dimensions of preforms) and the ability to use almost all available forms by the Early Bronze Age communities (Valde-Nowak 2000, 317). These suggestions will soon be revised to some extent, by the author of this article. Comprehensive analyses of Mierzanowice inventories have been carried out on the tools for the presence of the micro-traces of use.

In the Early Bronze Age in Lesser Poland, other techniques became more common than just the flaking method (techniques) of shaping a nodule of flint such as polishing (Piątkowska, Dobrzyński 2011, 113) and snapping (Kopacz 2001, 39). Regarding the classical Early Bronze Age inventories, there were no macroscopic traces of flint knapping, which is typical for the Neolithic period. It is confirmed by a very small contribution to techniques involving the use of a bone punch, pressure flaker or soft hammer percussor - wooden or antler (Migal 1997, 141).

c. Tools

The reduction model of a flint nodule aimed at obtaining flakes or blades with specific, desired forms by manufacturers (see Cotterell, Kamminga 1987) collapsed to a certain 

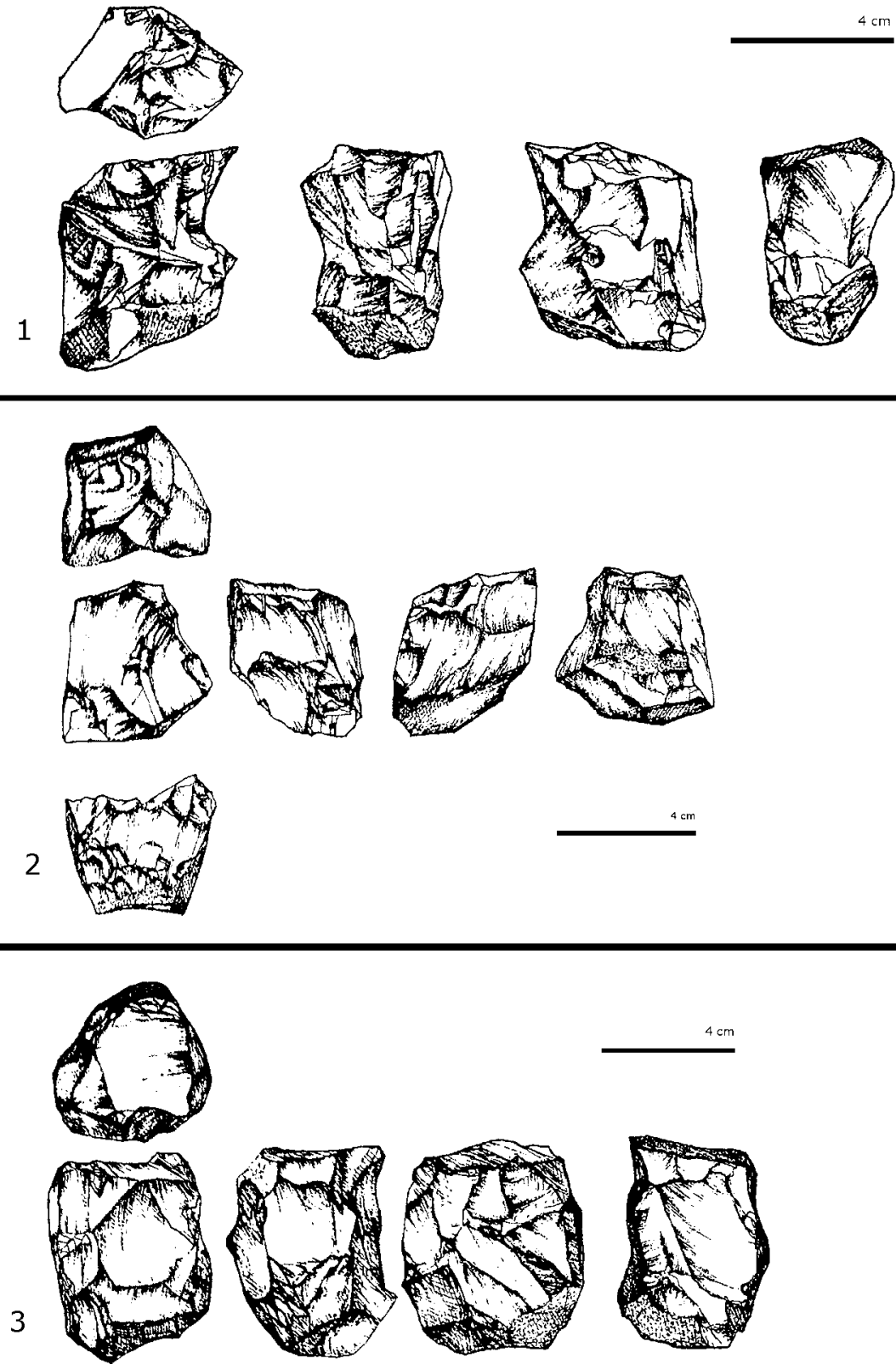

Fig. 3. Opatkowice, flint implements, Key: 1, 2, 3-cores (acc. to Valde-Nowak 2000) Ryc. 3. Opatkowice, wyroby krzemienne, gdzie: 1, 2, 3 - rdzenie (za P. Valde-Nowak 2000) 
degree in the course of the Early Bronze Age (see Fig. 4). This is due to the general disappearance of typological features of tools in the inventories (Lech 1982/1983, 53; Schild et al., 1985, 96; Kopacz, Valde-Nowak 1987, 79). Some researchers have even suggested that a significant part of used implements was only temporarily knapped or was not knapped at all (Kopacz, 2001, 39; see also Małecka-Kukawka 2001 for Neolithic inventories). However, this view, though probable, is associated with the need to carry out use-wear analyses for the representative, Early Bronze Age flint assemblages.

In the case of settlements, it is visible that there was a limitation of flint production to a narrow set of flint tools, despite the convenient location to raw material deposits (Kopacz, 1976, 95; Kadrow 1995a, 80; Kadrow 1995b, 244). On the contrary to this finding, the appearance of products with distinct morphological features (bifacial knapping) was noticeable, proving their specific functions and the special skills of those who knapped these products. The products have been called "conventional tools" and it was possible to distinguish among them sickles (Fig. 5: 4, 5, 8, Fig. 6: 5-8), daggers (Fig. 5: 1, 3, 6, 7), as well as axes and arrowheads (Kopacz, Valde-Nowak 1987, 78). These objects were often deposited as grave goods or hoards (see Kadrow 1995a, 80; Kopacz 2001, 39). Heart-shaped arrowheads with an arched undercut base were common forms (Fig. 5: 2; 7), often affiliated to the Mierzanowice culture (Borkowski, 1987, 161-167, Fig. 20). They were obtained, according to Budziszewski, as a result of amorphous core flaking (1991, 194, see Fig. 6: 9 and the comments above). In a large group of these artefacts a clearly intentional serrated edge can be seen (Borkowski, Kowalski 1997, 205-214). These arrowheads are often discovered in the grave inventories of the Mierzanowice culture (Salewicz 1937 Baczyńska 1993). However, it seems that we should not combine them with this culture only (see Borkowski 1997, 205-214).

It is necessary to mention dihedral axes with a lenticular cross section, they are a more common form when compared to the differentiated bifacial form. These products are rare in the inventories of the Corded Ware culture (Machnik 1966, 160; Włodarczak 2006, 2028), especially in the late horizon of this culture (Budziszewski, 1991, 206). Whereas, they are typical for the Early Bronze Age in Lesser Poland (see Salewicz 1937, 58-59; Głosik 1968, 53; Kopacz, 1976, 96-97; Balcer 1977, 198; Kopacz, Valde-Nowak 1987, 60). Budziszewski regards the emergence of the dihedral axes as a specific phenomenon. The specific regionalization of the phenomenon is noticeable and associated with the function of various production centres of axes (more Budziszewski 1991, 206). It is worth mentioning that the production flakes of these products were sometimes retouched (Budziszewski, 1991, 204).

The Early Bronze Age complexes contain more or less numerous forms defined generally as side-scraper forms and slender knife-shaped and backed tools (Schild et al. 1977, 94; Balcer 1977, 199; Kopacz, Valde-Nowak 1987, 80; Budziszewski 1991, 194; Valde-Nowak 2000, 317). The inventories also contain the occasional core tool of a lance-like shape (Kopacz 1976, table. II: 9, III: 1; Machnikowie, Kaczanowski 1987, fig. 13: 15, 16: 11), often regarded as 

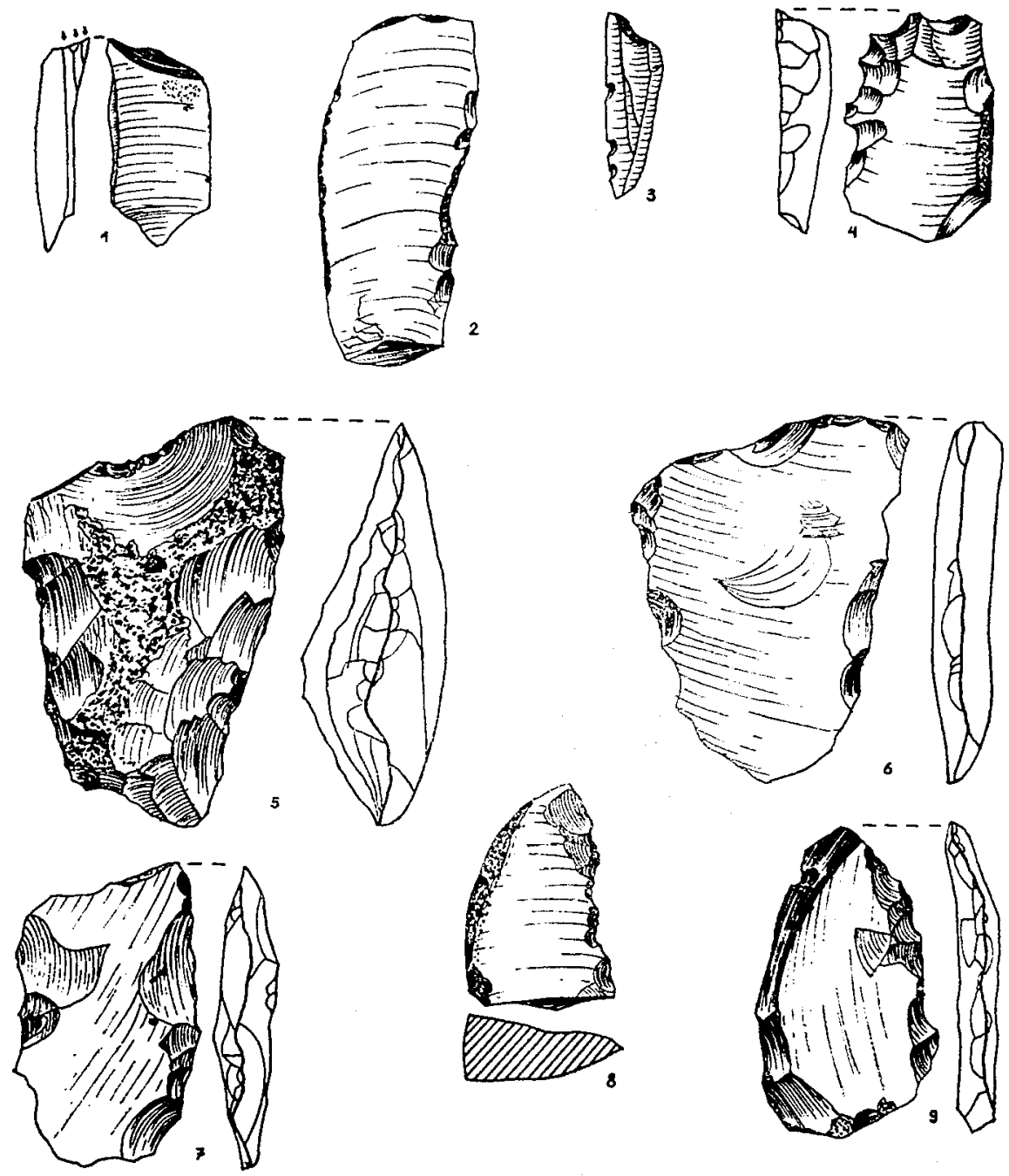

$5 \mathrm{~cm}$

Fig. 4. Iwanowice, flint implements, Key: 1 - burin, 2 - retouched blade, 3 - truncation, $4-$ end scraper, 5 - unfinished axe, 6-8 - knife-like tools, 9 - side-scraper (acc. to Kopacz 1976)

Ryc. 4. Iwanowice, wyroby krzemienne, gdzie: 1 - rylec, 2 - wiórowiec, 3 - półtylczak, 4 - drapacz, 5- siekiera niewykończona, 6-8 - narzędzia nożowate, 9-zgrzebło (za J. Kopacz 1976) 

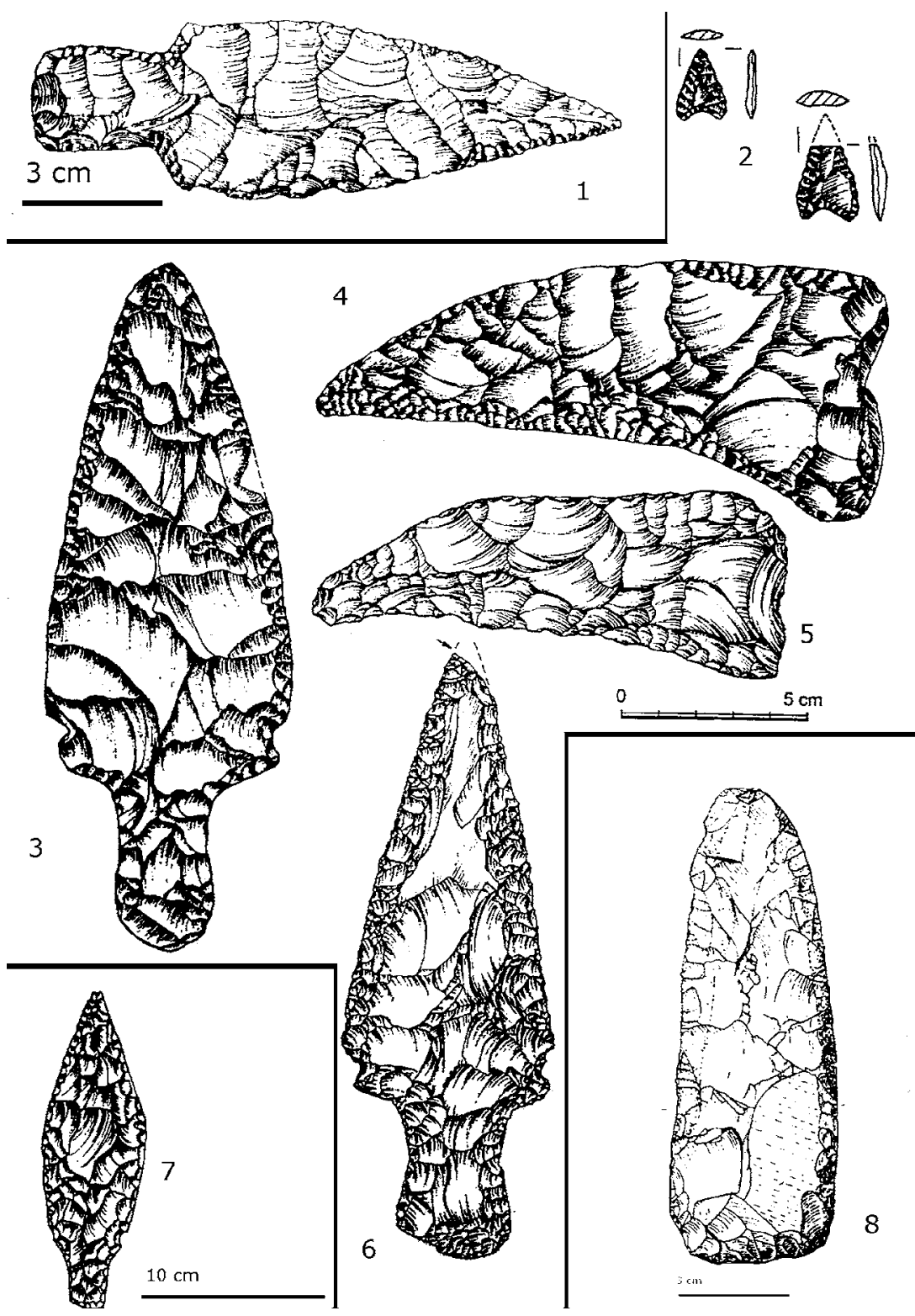

Fig. 5. Bifacial flint implements, Key: 1 - dagger, Torczyn (acc. to J. Fitzke 1975), 2 - heart-shaped arrowheads, Bondyrz (acc. to Balcer et al. 2002), 3, 6- daggers, Bliżów (acc. to Balcer et al. 2002), 4 - sickle, Bliżów (acc. to Balcer et al. 2002), 5 - sickle, Hucisko (acc. to Balcer et al. 2002), 7 - dagger, Torczyn (acc. to Svešněkov 1974), 8 - sickle, Mierzanowice (acc. to Bąbel 1974)

Ryc. 5. Krzemienne wyroby bifacjalne, gdzie: 1 - płoszcze, Torczyn (za J. Fitzke 1975), 2 - grociki sercowate, Bondyrz (za B. Balcer i in. 2002), 3, 6 - płoszcza, Bliżów (za B. Balcer i in. 2002), 4-sierp, Bliżów (za B. Balcer i in. 2002), 5 - sierp, Hucisko (za B. Balcer i in. 2002), 7 - płoszcze, Torczyn (za Ě. K. Svešněkov 1974), 8 - sierp, Mierzanowice (za J. Bąbel 1974) 

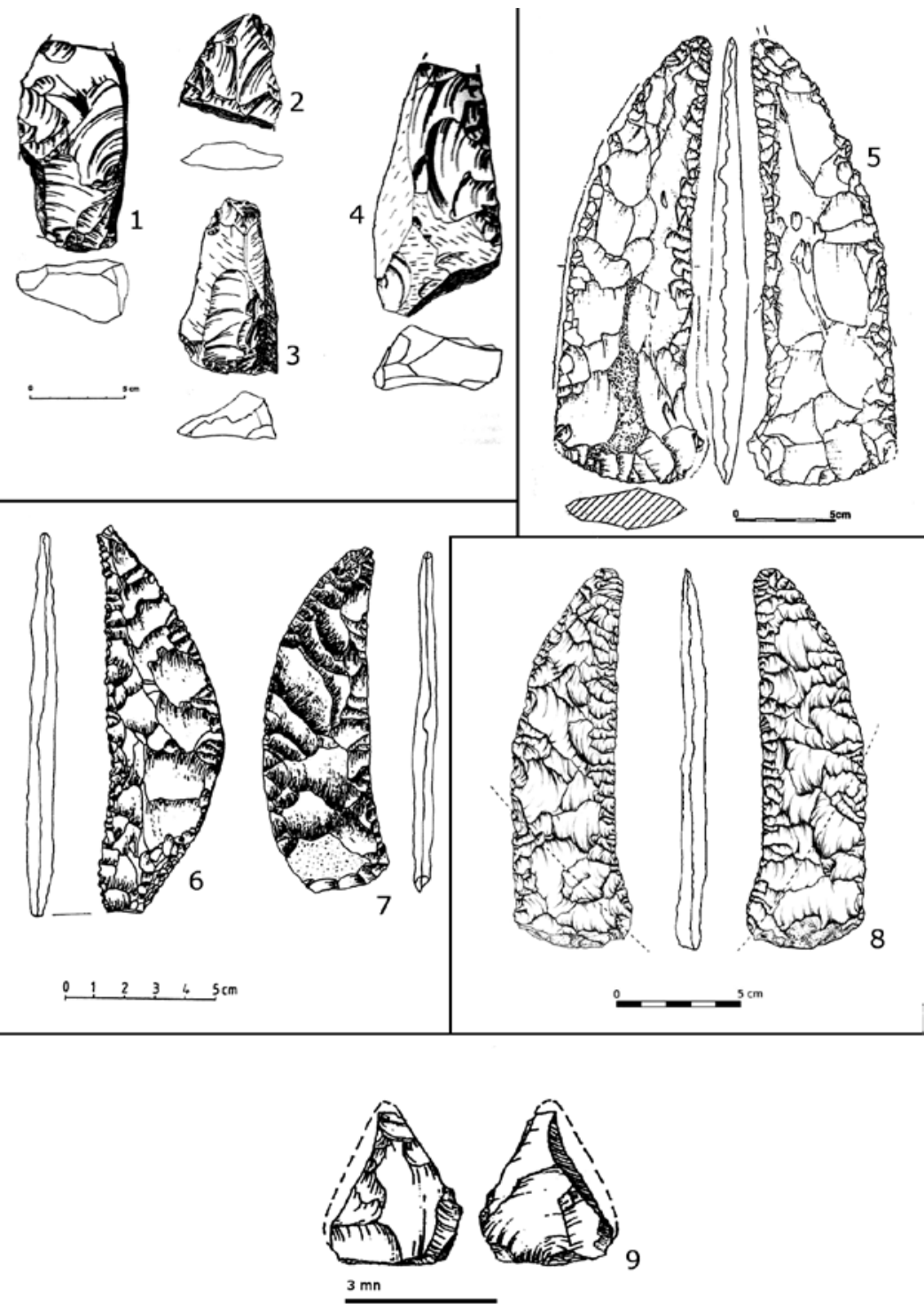

Fig. 6. Flint implements, Key: 1, 2, 4- fragments of initial forms of sickles, 3-abandoned form of dihedral axe, „Za Garncarzami” in Ożarów (acc. to Budziszewski 1998), 5 - sickle, Dachnów (acc. to Libera 2010), 6 - sickle, Szychowice (acc. to Bargieł et al. 1999), 7 - sickle, Obrowiec (acc. to Bargieł et al. 1999), 8 - sickle, Skołoszów (acc. to Piątkowska, Dobrzyński 2011), 9 - damaged initial form of heartshaped arrowhead (acc. to Budziszewski 2008)

Ryc. 6. Wyroby krzemienne, gdzie: 1, 2, 4 - fragmenty zaczątkowców sierpów, 3- zaniech siekiery dwuściennej, „Za Garncarzami” w Ożarowie (za J. Budziszewski 1998), 5 - sierp, Dachnów (za J. Libera 2010), 6 - sierp, Szychowice (za B. Bargieł i in. 1999), 7 - sierp, Obrowiec (za B. Bargieł i in. 1999), 8 - sierp, Skołoszów (za K. Piątkowska, M. Dobrzyński 2011), 9 - uszkodzony zaczątkowiec grocika sercowatego (za Budziszewski 2008) 
mining tools. Moreover, there were fairly massive end scrapers (Kopacz 1976, table. III: 6-9) and piercers (Kopacz 1976, table. II: 7, 8, IV: 12) recorded in the collection. The tool collection was supplemented by hammer stones.

This characteristic gives a picture of the Early Bronze Age flint manufacture from Lesser Poland. The economy of raw materials, knapping technology and tool structure seem to be similar across the zone. The extensions of specific products (daggers and sickles) do not refer to cultural boundaries (Fig. 1; 2). The areas of their production also do not comply with these borders. Numerous workshops of sickles or daggers could concentrate on the border between the Mierzanowice and Strzyżów cultures (Kadrow 1995a, 82). According to the findings presented by Libera, the production area of daggers and sickles were limited to Volyn territory - on the Styr and Horyn Rivers, to a lesser extent Podolia - at the Dniester River (Libera 2010, 17). It is noticeable that the frequency of their occurrence is concentrated in the western part of Lesser Poland and clearly increases from west to east, from the Wisłoka River (see Fig. 1; 2).

The presented issues are accompanied by a few other questions requiring discussion. First, it can be assumed that the material from the cemeteries had been specially selected, and does not reflect the tool structure, functioning in everyday life of the Early Bronze Age communities. Moreover, there were numbers of Neolithic redeposits in the Early Bronze Age graves (e.g. Szarbia). The same issue applies to the artefacts coming from the settlements. The Early Bronze Age materials were also mixed with Neolithic remains by the use of post-depositional processes. While the tools typical of the late Neolithic period, such as tetrahedral axes, are easy to detect (among others Bargiel 2002, 125), it is more difficult to distinguish less characteristic artefacts or simply preforms. It is also necessary to consider that the finds of flint products might have been waste fragments of flint, not suitable (in the eyes of users) for further work.

In the case of stray finds, the chronology of daggers seems uncertain. It is not clear when its manufacture ceased. It is much easier is to obtain dates for the sickles, as they are associated to the late phase of Mierzanowice culture, based on undisturbed burial contexts.

As for the materials coming from the mining sites, it is difficult to establish their cultural and chronological classification. They are rich in various waste fragments. In working places they were often left blank in their initial or abandoned forms (Fig. 6: 1-4, 9). The sites of this type often contain a variety of artefacts suggesting there could have been several hundred or even several thousand mining actions, during which the miners not only took up mining, but also flaking and settlement activities (Budziszewski 1998, 287). According to Budziszewski "[...] trying to determine the cultural affiliation of users of individual mines must refer to the significance of workshop artefacts discovered at the mining sites" (Budziszewski 1998, 290). 


\section{TECHNOLOGY, SOCIETY — THE ISSUES OF BIFACIAL TOOLS OCCURRING WITH PARTICULAR CONSIDERATION TO DAGGERS AND SICKLES}

The primary research tool with regards to the Early Bronze Age bifacial flint implements from Lesser Poland was the typological method. The division into cultural and chronological horizons of daggers and sickles was proposed by Libera (2001). This was done on the basis of analysis of the morphometric features of these implements (Libera 2001, fig. 37: 125; 39: 129). This approach, however, is accompanied by a number of doubts. Only a small proportion of the remains come from graves (daggers - about $7 \%$, sickle-shaped knives - nearly 4\%). Daggers are often the only accompanying grave good belonging to the deceased (Libera 2001, 132). Eighty-seven percent of the entire set of these artefacts recorded from Poland and western Ukraine are considered to be stray finds (Libera 2001, 77). The sickle-shaped knives, which make up 91.77\%, are also surface finds which have no archaeological context (Libera 2001, 92). As for the studied sickles, only minor differences in the shape of the tip were observed. Whereas, there were no other morphological and metric differences (Bargieł, Libera 1997, 155). In addition, an extensive system of horizons considering daggers and sickles was created on the basis of a number of "secondary" analogies. They have been determined on the basis of previously separated types that have been researched with reference to a small number of materials of a certain chronology.

Therefore, it seems appropriate to simplify the division of bifacial forms proposed by Libera (2001). It seems reasonable to approve horizon I of daggers for the Early Bronze Age without any subdivision into sub-phases. horizon II can be combined with a secondary use of the daggers by the Trzciniec culture population. It is reasonable to uphold also horizon I of the occurrence of sickles with no division into sub-phases, and at the same time moving their dating to the late phase of the Mierzanowice culture (see Kadrow, Machnik 1997, 83; Kadrow 2000, 142). The confirmation is the separation of the late horizon of crescent-shaped sickles for the Trzciniec and Lusatian cultures (see Bargiel et al., 1999). However, it should be noted, that the criterion for distinguishing the chronological framework of sickles is adopted in this case using the difference in the morphological shape of their base. In addition, crescent sickles often have the distinguished characteristic of a denticulated retouch formed on the inner edges (Libera 2001, 59). Related morphologically to the sickles are sickle inserts, in terms of size they are almost miniature, which are not known in the Early Bronze Age complexes (see Libera 2001, 99).

It is worth mentioning the fact that the flint tools were the subjects of certain modifications in various types, depending on the needs of the knappers and the users (see Budziszewski 1991, 193), as it was presented by means of an example of repeatedly reshaped, extremely overused fragments of a bifacial dagger found in grave No. 6 in Miernów 


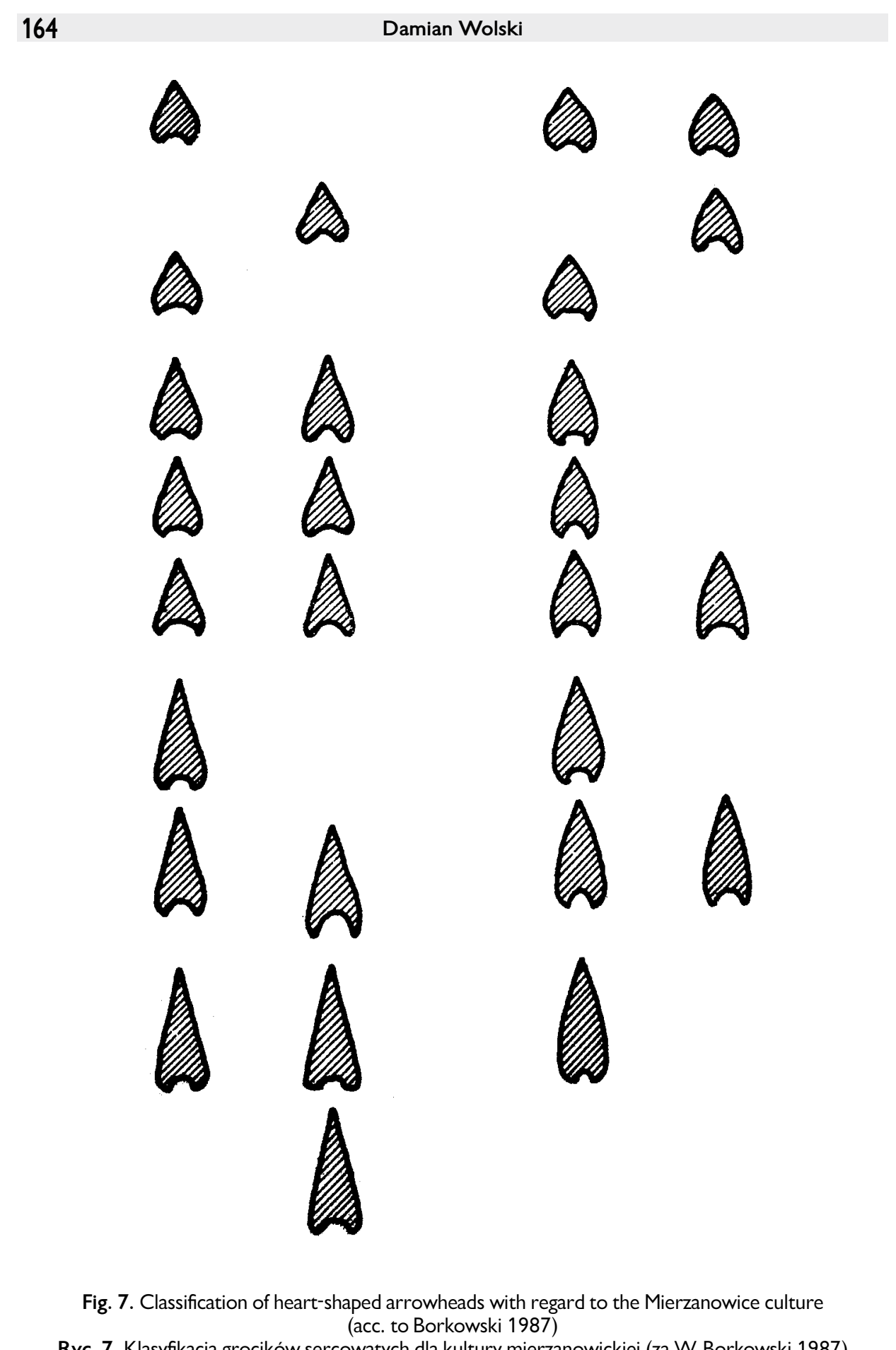


(Kempisty 1978, fig. 22:5 after Budziszewski 1991, 199). Additionally, changes in the morphology could result in functional changes of the tool. The same could take place in the case of other specimens of bifacial surface flaking. Uncritical recognition of the discovered flint implements as the desired forms to which the flint workers aspired, might be incorrect (see Grace 1997). We should also pay attention to another observation made by Libera. As for the Early Bronze Age sickles, plenty of them had sharp, rounded or broken tops (“wide-top sickle-shaped knives”) (Libera 2001, 95). Rounding or breaking the top does not necessarily indicate the intention of the manufacturer, it could have been caused by some repair work or intensive use.

Therefore, it is worth considering the issue of bifacial implements from different points of view, in order to comprehend the reasons and rules for their functioning in society. As illustrated, the tools of daggers and sickle types are clear diverging products of technology that regards the raw materials from the common flake forms known from Lesser Poland. Perhaps this kind of dichotomy of flint working is a reflection of the existence of certain specific standards of behaviour seen within the Mierzanowice community with regard to technology (see Apel 2001).

A chance to respond to the issue is provided by the concept of the "chain of operations" (chaîne opératoire; Pelegrain 1990) as well as the theory being influenced by the society outlined by Aronson on the basis of social psychology (Aronson 1997; 2009). The approach mentioned as the first one, the sequence of activities undertaken by the manufacturers of the tools and the role they played is emphasized (Pelegrain 1990, Bar-Yosef, van Peer

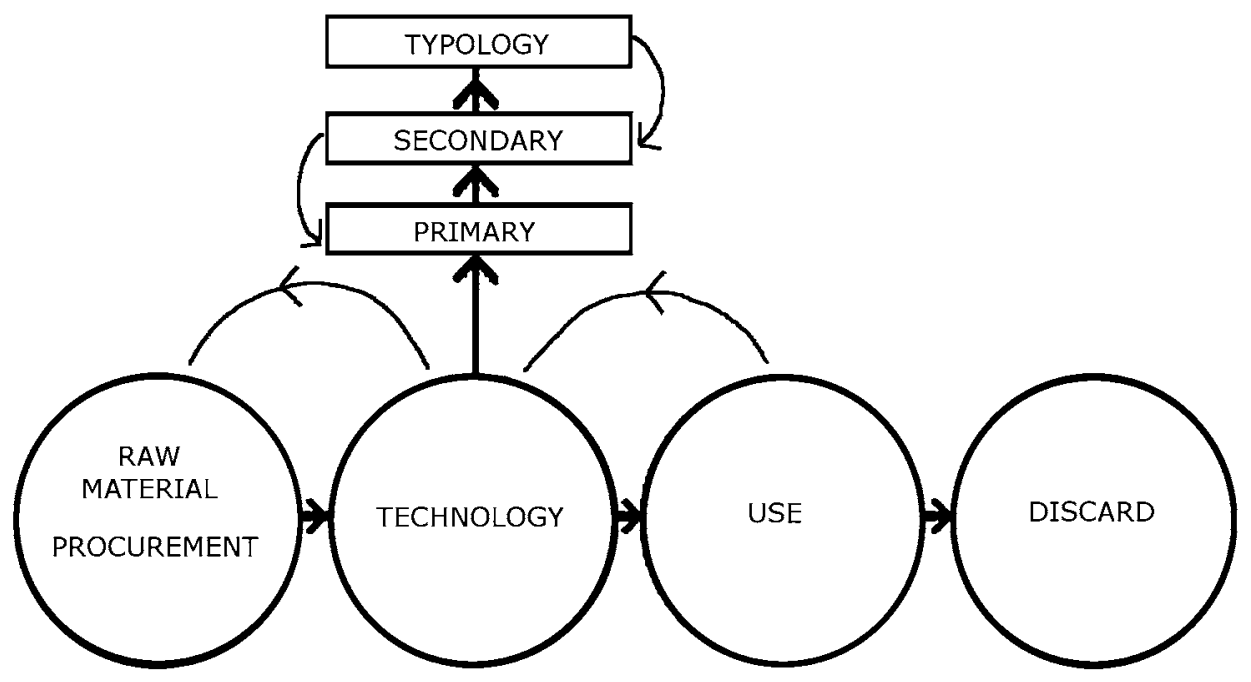

Fig. 8. An example of a chain operation (acc. to Grace 1997)

Ryc. 8. Przykładowy łańcuch operacji (za R. Grace 1997) 
2009). The concept presumes there was a necessity to perceive all possible processes taking place in the use of raw flint materials (Fig. 8). This "chain of operations" covers particular steps associated with the use of flint by the community - from the discovery of raw materials and their exploitation, by selection, transport, knapping, tool use, possible recycling and reuse, up to abandoning the artefacts (e.g. Grace 1997). This theory refers to the controlled decision-making strategies for each of the above mentioned steps and to the technical acts ("gestures") that particular individuals learn through "immersion" in the culture. Due to this approach, we are closer to understand the diversity of flint material or "read the signs" referring to the decisions taken by the producers and users of tools (Banning 2000, 141).

In light of this theoretical concept, flint implements need to be perceived as traces of human behaviours. There is no doubt that the manufacture of bifacial tools is an extremely complex process. It is not limited to a simple repetition of technical gestures. At the stage of knapping, it is necessary to monitor critically situations that could arise (the system of negative scars, angles, curves) and take decisions concerning the best possible technological solutions. It is necessary to have the imagination about the product. The knapper has in his mind an ordered sequence of steps organized into a conceptual diagram of the operations (see Pelegrin, 116-125). Most likely, these skills were possessed by only a few craftsmen. It has been confirmed by archaeologists who have dedicated many years of experiments related to the flint knapping (among others W. Migal and J. Pelegrin).

The whole technological competence includes two main parts (Fig. 9). The first component is conscious connaissance (knowledge). This step determines how to deal with particular sequences of the technological process (e.g. what tools, technical procedures must be used). Knowledge is "communicative". It takes place between a teacher and a pupil by means of observation and conversation (Pelegrin 1990, 118). This knowledge should be seen as an explanation, communication and as a theoretical memory only - where the words are "two-dimensional" (Apel 2001, fig. 2.1., 28).

The second component is unconscious connaissance (know-how). It includes obtaining skills - imitation and learning by trial and error, as well as the acquisition of knowledge regarding the fact that familiarity with technology is always associated with the practice. Know-how is a kind of "unconscious" competence. It wakes up in practical experiments (Pelegrin 1990, 118). This kind of competence is expressed through action, intuition, unconscious memory - not lost even in the case of loss of memory. They are no longer "twodimensional" words, but the memory is pictorial (3D) (Apel 2001, fig. 2.1., 28).

Only conscious acquisition of knowledge is not sufficient for the production of advanced tools (e.g. bifacial daggers). Such manufacture requires advanced know-how that can be achieved only on the basis of practical experience (Apel 2001, 29). It is imperative that manufacturers of daggers and sickles have the skills to combine conscious and unconscious knowledge as well as they should understand that both aspects are equally important (see Schiffer, Skibo 1987, 597). 


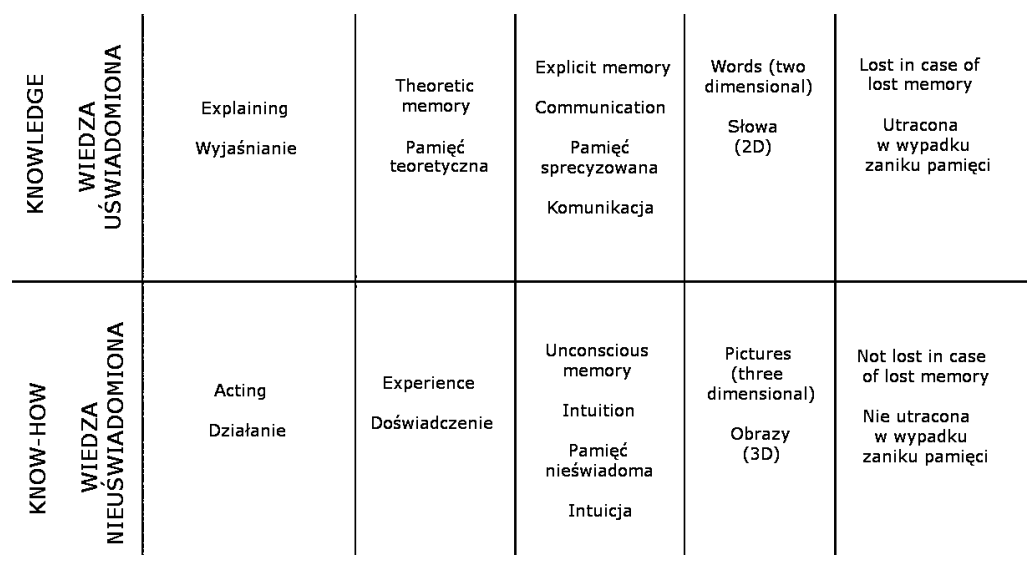

Fig. 9. The main elements of conscious (knowledge) and unconscious (know-how) technological competence (acc. to Apel 2001)

Ryc. 9. Główne elementy wiedzy technologicznej uświadomionej (knowledge) i nieuświadomionej (know-how) (za J. Apel 2001)

As it was presented in the article, the bipolarity regarding the development of flint working in the course of the Early Bronze Age in Lesser Poland allows us to draw certain conclusions. It seems that the access to the technological knowledge considering the production of daggers and sickles was very limited. Competence of their production might have been in the hands of a very small number of specialist groups; perhaps entire wandering families (see remarks of Robinson et al. 2004, 150-151). To hold the tradition of producing bifacial tools for centuries there had to be some education system with respect to flint working and technological practices (see Apel 2001, 18-19). This view should be applied to the observation and analysis of other technologies, which also occurred within the Early Bronze age community of Lesser Poland, namely the production of faience beads (Robinson et al. 2004). Robinson perceives its sourcing as relatively simple and affordable to the majority of the Mierzanowice population (Robinson et al. 2004, 139). To produce faience beads, it was enough to have the necessary theoretical base (knowledge) and a resource base (Robinson et al. 2004, 139), by contrast to the complex technology and skill required to produce daggers and sickles. In this case, in addition to the availability of adequate raw flint materials (see Apel 2001, 30) and the acquisition of conscious knowledge, it was extremely important to have the unconscious competence (know-how). Acquiring it was always associated with intense training from an early age ("immersion" in the culture"; Pelegrin 1990, 118).

The aforementioned data allows us to consider flint knapping as a part of a larger technological system or systems handed down from generation to generation (Banning 2000, 141). This phenomenon is explained in some way by social psychology. It seems that the 
unity of aims and practices of manufacturers who implemented daggers and sickles, supported by cultural tradition, favoured a disclosure of the conformist behaviour of the community (Aronson et al. 1997, 278-296). The researchers point out that as for the implementation of technology it was necessary to organize the function of authority-teachers. Only the effective functioning of these specific social roles can efficiently stimulate the transfer of technological knowledge to the next generation (Apel 2001, 30). So how was the relationship between the teacher and pupil? How could technological knowledge be transferred? Well, this could happen under the influence of certain social pressures (Aronson $e t$ al. 1997). With regard to the teacher-pupil relationship, there are always two types of conformity - the information conformism and normative conformism (Aronson et al. 1997, 299-306). The first of them may appear if the pupil takes lessons of technology. Then, he is in a situation previously unknown and has difficulty with shaping behaviours desired by the teacher. The authority provides the student with information, who in turn repeats learned behaviour in similar circumstances in the future (Aronson et al. 1997, 268-269). Normative conformity is usually motivated by the fear of being rejected by the group, or the desire to be accepted by it. The authority provides in such conditions the conviction of rightness of their actions (Aronson et al. 1997, 278-279). He is by himself the determinant of acceptable standards. Thus, there was a compliance with the rules determining the need to take up and promote the further study of technology. On the basis of the points mentioned above, it is possible to state that information and normative pressures might cause an escalated level of obedience (Aronson et al. 1997, 307). As a result of these practices, the students gained both conscious knowledge and practical skills. Such knowledge was passed on to the next generation of flint workers.

Another factor ensuring stability and continuity of flint knapping tradition for a couple of centuries could be the internalization of social norms. Groups of craftsmen followed values which had been ingrained in them for a long time (Aronson et al. 1997, 287-288). Moreover, speaking of specialists, the submission pressure exerted on the individual was much larger in comparison to normal conditions (Aronson et al. 1997, 290-299; see also Newcomb et al. 1970, 508-514). The motive to aspire to rightness within these groups was a powerful and self-sustaining force, independent of constant supervision, associated with the system of reward and punishment. Progressive thoughtless conformity affected the groups of daggers and sickles manufacturers in a significant way so that individuals mechanically referred to the specific behaviours (Aronson et al. 1997, 287-289). These hypotheses further enable us to understand how these amazing bifacial forms came into production and why their production continued for a couple of centuries.

In the light of the presented theoretical model, putting aside the utilitarian functions of bifacial forms -which has been confirmed by means of microscopic analyses conducted by Bąbel and Budziszewski (1978) as well as Balcer and Schild (1980), it is necessary to maintain the hypothesis of their mainly symbolic nature (see among others Kadrow 1995a , 80). It should be noted that the manufacturers of these prestige implements were not necessarily 
their users. The phenomenon of the spread of daggers and sickles can be interpreted as the result of physical migrations, perhaps as a consequence of trade or exchange or as a result of personal contacts with the producers in the course of various types of trans-regional celebrations. Despite the fact that the evidence of daggers and sickles was clear for the Mierzanowice population, there is an almost total absence of these implements in the settlement context. Moreover, strikingly is the fact that a very small amount of production material came in the form of flakes, often associated with the formation of these tools (see Budziszewski 1991, 196). The occurrence of these forms can be understood as proof that there was a demand for prestige products, confirming the existence of a prestige technology in the Early Bronze Age in lesser Poland (see Olausson 2000, 128; Apel 2001, 330). The proposed hypothesis cannot be rejected due to the fact that the vast majority of accidental daggers and sickles finds were clearly linked to the sepulchral context. Considering this "randomness", it is not possible to exclude a specific form of burial type that by the use of current prospecting and exploration techniques, is not recorded (see Balcer et al. 2002, 146, Libera 2010, 16).

\section{CONCLUSIONS}

The presented analysis of flint working allows us to define the economy concerning raw materials and tools exploited by the Early Bronze Age community from Lesser Poland as self-sufficient (Kopacz, Valde-Nowak 1987, 75; Kadrow 1995b, 241-245). The production and use of simple tools, made from flakes should not be linked to the impact of the current fashion. This manufacture should be seen as evidence of economic efficiency (Kadrow 1995a, 78). Having bifacial tools of dagger and sickle types was not a necessary condition for the implementation of standard economic needs (see Kopacz, Valde-Nowak 1987, 76). A typical Early Bronze Age community from Lesser Poland was able to exist completely without these implements, which is illustrated by the numerous examples of settlement materials (among others Iwanowice) (Kadrow 1995a, 80).

The theoretical concepts presented in this paper lead to the conclusion that the main traditional role, which was understood to have had an emotional bond with the past was limited primarily to the production of daggers and sickles. The phenomenon of their manufacturing expertise was conditioned by a strong social impact of technology teachers, who supported a system (or systems) of flint knapping competences. Also of significance is the hypothesis of a strong internalization of social norms with respect to the technological tradition.

The spread of daggers and sickles was probably a consequence of the flow of ideas. The transmission of technological knowledge through the narrow channels within their own group (or groups) disrupted the access to the secret of their production. In the face of flourishing specialization considering the Early Bronze Age production in Europe (Robin- 
son et al. 2004, 150-151), it seems reasonable to accept the hypothesis of the existence of groups of craftsmen in the Lesser Poland region, perhaps with entire wandering families of specialists, engaged in the manufacture of daggers and sickles. In this context, it would be justified to take a view of the over-regional and cross-cultural nature of the bifacial tools in the Early Bronze Age societies (see remarks of Bargieł, Libera 2004, 180-184; Dzbyński 2008, 262).

\section{ENDING}

This article should be treated as an attempt to present the general characteristics of the Early Bronze Age flint inventories in Lesser Poland. What is more, a theoretical model which refers to the specialization of the production and demand for the prestige products within these communities was proposed. I believe that the presented issues will provoke a discussion of new research opportunities concerning flint working, aimed at specific interpretations of social phenomena in prehistory. The chance emerges through the use of interdisciplinary discourse and was attempted for this paper. On this occasion, the findings relating to specific models of society, known from the circle of human sciences have been used.

I realize that some of the statements contained in the article may seem controversial, and the adoption of the presented research perspective is difficult to accept. I know that these interpretations should have had more conclusive confirmations with regard to specific archaeological materials. It is my goal to do so in my further research.

\section{References}

Andrefsky W. 1998. Lithics: Macroscopic Approaches To Analysis. Cambridge.

Apel J. 2001. Daggers. Knowledge \& Power. Uppsala.

Aronson E. 2009. Czlowiek - istota społeczna. Warszawa.

Aronson E., Wilson T. D. and Akert R. M. 1997. Psychologia spoleczna. Serce i umyst. Poznań.

Baczyńska B. 1993. Cmentarzysko kultury mierzanowickiej w Szarbii, woj. kieleckie. Studium obrządku pogrzebowego. Kraków.

Balcer B. 1971. O stanie i potrzebach w zakresie badań krzemieniarstwa neolitu i wczesnej epoki brązu. Wiadomości Archeologiczne 36, 51-70.

Balcer B. 1977. Osada kultury mierzanowickiej na stanowisku 1 w Mierzanowicach, woj. tarnobrzeskie, Wiadomości Archeologiczne 42, 175-212.

Balcer B. 1991. Z badań przemysłu mierzanowickiego na Roztoczu. Lubelskie Materiały Archeologiczne 6, 341-349.

Balcer B., Machnik J. and Sitek J. 2002. Z pradziejów Roztocza na ziemi zamojskiej. Kraków. 
Balcer B. and Schild R. 1978a. A jednak sierpy! Z otchtani wieków 44, 44-49.

Balcer B. and Schild R. 1978b. Sierpem i głowę można uciąć. Z otchłani wieków 44, 145-147.

Balcer B. and Schild R. 1980. Traces of Wear and Stone Function: Do They realy Mean What They Show? In. R. Schild (ed.), Unconventional Archaeology. New Approaches and Goals in Polish Archaeology. Wroclaw, 109-116.

Banning E. B. 2000. The archaeologist's laboratory: the analysis of archaeological data. New York.

Bar-Yosef O. and Peer P. van. 2009. The Chaine Operatiore Approach in Middle Paleolithic Archaeology. Current Archaeology 50, 103-131.

Bargieł B. 2002. Stan badań nad wykorzystaniem krzemienia świeciechowskiego w późnym neolicie i epoce brązu w Polsce południowo-wschodniej (zarys problematyki). In. Matraszek B., Sałaciński S. (eds.), Krzemień świeciechowski w pradziejach: Materiały z konferencji $w$ Ryni, 22-24.05.200o. Warszawa, 123-140.

Bargieł B. and Libera J. 1996. Wyniki badań pracowni nakopalnianej w Nowym Rachowie. Archeologia Polski Środkowowschodniej 1, 35-48.

Bargieł B. and Libera J. 1997. Z badań nad formami bifacjalnymi w Małopolsce. In. Lech J. and Piotrowska D. (eds.), Z badań nad krzemieniarstwem epoki brazu i wczesnej epoki żelaza: Materiały z sympozjum zorganizowanego $w$ Warszawie 20-22 października 1994 r. Warszawa, $145^{-161 .}$

Bargieł B. and Libera J. 2004. „Groty typu strzyżowskiego” - mit a rzeczywistość. In. Libera J. and Zakościelna A. (eds.), Przez pradzieje i wczesne średniowiecze. Księga jubileuszowa na siedemdziesiąte piąte urodziny docenta doktora Jana Gurby. Lublin, 169-187.

Bargieł B. and Libera J. 2005. Zespoły grobowe z krzemiennymi płoszczami w Małopolsce i na Wołyniu. Wiadomości Archeologiczne 57, 3-27.

Bargieł B., Libera J., and Panasiewicz W. 1999. Półksiężycowate sierpy krzemienne z okolic Hrubieszowa. Archeologia Polski Środkowowschodniej 4, 240-250.

Bąbel T. 1974. Krzemienne kindżały kultury mierzanowickiej. Z otchtani wieków 40, 151-154.

Bąbel T. 1987. Obrządek pogrzebowy we wczesnym okresie epoki brązu na Wyżynie Opatowskiej.

Kraków (unpublished doctor thesis stored in Archiv the Institute of Archaeology and Ethnology, Polish Academy of Sciences).

Bąbel T. and Budziszewski J. 1978. Noże wielofunkcyjne? W sprawie ostrzy z Mierzanowic polemiki ciąg dalszy. Z otchtani wieków 44, 139-145.

Borkowski W. 1984. Technologia wykonania i morfologia grocików sercowatych z przełomu neolitu i wczesnej epoki brązu na Wyżynie Małopolskiej. Warszawa (unpublished master thesis stored in Archiv of the Institute of Archaeology, Warsaw University).

Borkowski W. 1987. Neolithic and Early Bronze Age heart-shaped arrow heads from the Little Poland Upland. Archaeologia Interregionalis 8, 147-181.

Borkowski W. and Kowalewski M. 1997. Krzemienne groty strzał z epoki brązu z terenów Mazowsza i Podlasia. In. Lech J. and Piotrowska D. (eds.), Z badań nad krzemieniarstwem epoki brazu i wczesnej epoki żelaza: Materiaty z sympozjum zorganizowanego $w$ Warszawie 20-22 października 1994 r. Warszawa, 205-214. 
Borkowski W., Migal W., Sałaciński S. and Zalewski M. 1989. Urgeschichtlicher Feuersteinbergbau im Gebiet von Krzemionki. Ein Bericht zum Stand der Forschung. Praehistorische Zeitschrift 64, 164-207.

Budziszewski J. 1987. Wykorzystanie tzw. krzemienia czekoladowego przez ludność Wyżyny Środkowopolskiej na przełomie neolitu i epoki brazu. Warszawa (unpublished doctor thesis stored in Archiv the Institute of Archaeology, Warsaw University).

Budziszewski J. 1991. Krzemieniarstwo ludności Wyżyny Środkowopolskiej we wczesnej epoce brązu. Lubelskie Materiaty Archeologiczne 6, 181-208.

Budziszewski J. 1998. Świętokrzyski Okręg Pradziejowej Eksploatacji Krzemieni w dobie kultury trzcinieckiej. In. Kośko A. and Czebreszuk J. (eds.), Trzciniec - system kulturowy czy interkulturowy proces? Poznań, 286-299.

Budziszewski J. 2008. Stan badań nad występowaniem i pradziejową eksploatacją krzemieni czekoladowych. In. Borkowski W., Libera J., Sałacińska B. and Sałaciński S. (eds.), Krzemień czekoladowy $w$ pradziejach. Materiaty z konferencji $w$ Orońsku, o8-10.10.2003. WarszawaLublin, 33-106.

Chmielewska M. 1973. Badania stanowiska Polany II w pow. Szydłowiec w 1971 r. Sprawozdania Archeologiczne 25, 29-37.

Chmielewska M. 1988. The Early Bronze Age Flint Mine AT site II, Polany, Radom district. Przeglad Archeologiczny 35, 139-181.

Cotterell B. and Kamminga J. 1987. The Formation of Flakes. American Antiquity 52, 675-708.

Dzbyński A. 2008. Rytuał i porozumienie. Racjonalne podstawy komunikacji i wymiany w pradziejach Europy Środkowej. Rzeszów.

Fitzke J. 1938. Cmentarzysko kultury ceramiki sznurowej w Torczynie, pow. Łuck. Sprawozdania z czynności i posiedzeń PAU 43, 26-27.

Fitzke J. 1975. Cmentarzysko kultury strzyżowskiej w Torczynie pod Łuckiem na Wołyniu. Wiadomości Archeologiczne 40, 53-62.

Gijn A. L. van. 1988. The use ofe Bronze Age flint sickles in the Netherlands: a preliminary raport. In. Beyries S. (eds.), Industries lithiques. Traceologie et Technologie. (= Bitish Archaeological Reports. International Series 411). Oxford, 197-218.

Gijn A. L. van. 2010. Flint in Focus. Lithic Biographies in the Neolithic and Bronze Age. Leiden.

Głosik J. 1968. Kultura strzyżowska. Materiały starożytne 11, 7-114.

Grace R. 1997. The 'chaîne opératoire’ approach to lithic analysis. Internet Archaeology 2.

Jażdżewski K. 1981. Pradzieje Europy Środkowej. Wrocław.

K. J. (Konrad Jażdżewski?). 1936. Późnoneolityczna lub wczesnobrązowa pracownia sierpów w Sapanowie w pow. krzemienieckim. Z otchtani wieków 11, 93.

Kadrow S. 1995a. Gospodarka i spoleczeństwo. Wczesny okres epoki brazu w Matopolsce. Kraków.

Kadrow S. 1995b. Surface exploitation of the Jurassic flints in the Iwanowice microregion. Archaeologica Polona 33, 241-245.

Kadrow S. 2001. U progu nowej epoki. Gospodarka i spoteczeństwo wczesnego okresu epoki brąu $w$ Europie Środkowej. Kraków. 
Kadrow S. and Machnikowie A. i J. 1992. Iwanowice, stanowisko Babia Góra, part II. Cmentarzysko z wczesnego okresu epoki brązu. Kraków.

Kadrow S. and Machnik J. 1997. Kultura mierzanowicka. Chronologia, taksonomia, rozwój przestrzenny. Kraków.

Kempisty A. 1978. Schyłek neolitu i początek epoki brązu na Wyżynie Małopolskiej w świetle badań nad kopcami (= Rozprawy Uniwersytetu Warszawskiego 121). Warszawa.

Kondracki J. 2002. Geografia regionalna Polski. Warszawa.

Kopacz J. 1976. Wstępna charakterystyka technologiczno-typologiczna wczesno brązowego przemysłu krzemiennego z Iwanowic, woj. Kraków. Archeologia Polski 21, 22-26.

Kopacz J. 1978. Krzemieniarstwo wczesnej epoki brąu w Iwanowicach. Kraków (unpublished doctor thesis stored in Archive the Institute of Archaeology and Ethnology, Polish Academy of Sciences).

Kopacz J. 2001. Początki epoki brązu $w$ strefie karpackiej $w$ świetle materiałów kamiennych. Kraków.

Kopacz J. and Valde-Nowak P. 1987. Episznurowy przykarpacki krąg kulturowy w świetle materiałów kamiennych. Archeologia Polski 31, 55-92.

Kozłowski L. 1913. Siedziba neolityczna na Babiej Górze w Iwanowicach, pow. miechowski, gub. kielecka. Światowit 11, 15-41.

Kozłowski L. 1917. Badania archeologiczne na górze Klin w Iwanowicach, powiatu Miechowskiego (= Prace Towarzystwa Naukowego Warszawskiego 14). Warszawa.

Kozłowski L. 1923. Epoka kamienia na wydmach wschodniej części Wyżyny Matopolskiej. Lwów.

Kozłowski L. 1924. Młodsza epoka kamienia $w$ Polsce (neolit). Lwów.

Kraussowie J. and A. 1971. Cmentarzysko kultury mierzanowickiej w Świniarach Starych, pow. Sandomierz. Materiaty Archeologiczne 12, 109-136.

Lech J. 1981. Górnictwo krzemienia społeczności wczesnorolniczych na Wyżynie Krakowskiej. Koniec VI tysiaclecia - 1 polowa IV tysiaclecia p.n.e. Wroclaw.

Lech J. 1982/1983. Flint work of the early farmers. Productive trends in central European chipping industries from 4500-1200 b.c. Acta Archaeologica Carpathica 22, 5-63.

Lech J. 1997. Krzemieniarstwo postneolityczne i jego badania In. Lech J. and Piotrowska D. (eds.), $Z$ badań nad krzemieniarstwem epoki brazu i wczesnej epoki żelaza: Materiały z sympozjum zorganizowanego $w$ Warszawie 20-22 października 1994 r. Warszawa, 237-249.

Lech H. and J. 1984. The prehistoric flint mine at Wierzbica "Zele": a case study from Poland. World Archaeology 16, 186-203.

Libera J. 2001. Krzemienne formy bifacjalne na terenach Polski i Zachodniej Ukrainy (od środkowego neolitu do wczesnej epoki żelaza). Lublin.

Libera J. 2010. Krzemienne „groty”, „sztylety” oraz „sierpy” (przyczynek do studiów nad wybranymi wytworami krzemieniarstwa kultury mierzanowickiej). Rocznik Przemyski 46, 3-29.

Machnik J. 1966. Studia nad kulturq ceramiki sznurowej $w$ Matopolsce. Wrocław.

Machnik J. 1967. Stosunki kulturowe na przełomie neolitu i epoki brązu w Małopolsce (Na tle przemian w Europie Środkowej). Materiały do prahistorii ziem polskich 3. Warszawa. 
Machnik J. 1978. Wczesny okres epoki brązu. In Gardawski A. and Kowalczyk J. (ed.), Prahistoria ziem polskich 3. Wczesna epoka brąu. Wrocław, 9-136.

Machnikowie A. and J. 1973. Wczesnobrązowy zespół osadniczy na „Babiej Górze” w Iwanowicach, pow. Miechów, w świetle dotychczasowych badań wykopaliskowych. In Machnik J. (ed.), Z badań nad neolitem i wczesna epoka brązu w Małopolsce. Wrocław, 141-158.

Machnikowie A., J. and Kaczanowski K. 1987. Osada i cmentarzysko z wczesnego okresu epoki brazu na „Górze Klin” w Iwanowicach. Wrocław.

Małecka-Kukawka J. 2001. Między formą a funkcją. Traseologia neolitycznych zabytków krzemiennych z Ziemi Chetmińskiej. Toruń.

Migal W. 1997. Znaczenie przemysłu nakopalnianego z Rybnik, woj. białostockie, dla poznania krzemieniarstwa epoki brązu w Polsce. In. Lech J. and Piotrowska D. (eds.), Z badań nad krzemieniarstwem epoki brazu iwczesnej epoki żelaza: Materiahy z sympozjum zorganizowanegow Warszawie 20-22 października 1994 r. Warszawa, 129-143.

Młynarczyk 1983. Wstępne wyniki badań kopalni krzemienia czekoladowego Wierzbica „Zele”, woj. Radom w latach 1979-81. Sprawozdania Archeologiczne 35, 87-115.

Newcomb Th. M., Turner R. H. and Converse Ph. E. 1970. Psychologia spoteczna. Warszawa.

Olausson D. 200o. Talking axes, Social Daggers. In. Olausson. D. and Vandkilde H. (eds.), Form, Function and Context. Material culture studies in Scandinavian archaeology. Almqvist \& Wiksell International. Lund, 121-134.

Pelegrin J. 1990. Prehistoric Lithic Technology: Some Aspects of research. Archaeological Review from Cambridge 9, 116-125.

Piątkowska K., Dobrzyński M. 2011. Technologia bifacjalnych noży sierpowatych na podstawie znalezisk grobowych kultury mierzanowickiej ze Skołoszowa, st. 7, pow. Jarosław. Materiały i Sprawozdania Rzeszowskiego Ośrodka Archeologicznego 32, 107-115.

Podkowińska Z. 1936. Wykopaliska w Strzyżowie, prowadzone w lecie 1935 roku. Z otchłani wieków 11, 72-77.

Podkowińska Z. 1960. Badania w Strzyżowie, pow. Hrubieszów, woj. Lublin, w latach 1935-37 oraz 1939. Archeologia Polski 5, 39-80.

Robinson C., Baczyńska B. and Polańska M. 2004. Pochodzenie fajansu w Polsce. Sprawozdania Archeologiczne 56, 79-154.

Salewicz K. 1937. Tymczasowe wyniki badań prehistorycznych w Mierzanowicach, pow. Opatów, woj. kieleckie. Z otchłani wieków 22, 39-59.

Schiffer M. and Skibo J. 1987. Theory and Experiment in the Study of Technological Change. Current Anthropology 28(5), 595-622.

Schild R. 1971. Lokalizacja prahistorycznych punktów eksploatacji krzemienia czekoladowego na północno-wschodnim obrzeżu Gór Świętokrzyskich. Folia Quaternaria 39, 1-61.

Schild R., Królik H. and Marczak M. 1985. Kopalnia krzemienia czekoladowego w Tomaszowie. Wrocław.

Schild R., Królik H. and Mościbrodzka J. 1977. Kopalnia krzemienia czekoladowego z przełomu neolitu i epoki brazu w Polanach Koloniach. Wrocław. 
Svešnikov I. K. 1974. Istoriâ naselennâ Peredkarpattâ, Poděllâ i Volyně w kinci III - na počatku II tisjačolittâ do našod' eri. Kěd'v.

Valde-Nowak P. 200o. Zabytki krzemienne kultury mierzanowickiej z Opatkowic, gm. Proszowice. In Rydzewski J. (ed.), 150 lat Muzeum Archeologicznego w Krakowie. Kraków, 305-320.

Włodarczak P. 2006. Kultura ceramiki sznurowej na Wyżynie Małopolskiej. Kraków.

\title{
Damian Wolski
}

\section{WCZESNOBRAZOWE MATERIAŁY KRZEMIENNE Z MAŁOPOLSKI — PROBLEMY BADAWCZE, PROPOZYCJE INTERPRETACJI}

\author{
WSTĘP
}

Pomimo znacznego wzrostu zainteresowania krzemieniarstwem postneolitycznym w ostatnich latach (m. in. Lech 1997, 237-249; Kopacz 2001; Libera 2001), stanu wiedzy na ten temat nie sposób uznać za zupełnie zadowalający. Wciąż pojawiają się nowe pytania i wątpliwości w związku z hipotezami funkcjonującymi w literaturze nawet od kilku dziesięcioleci. Konieczne jest dokonanie zasadniczego przeglądu dotychczasowych ustaleń, ich weryfikacja i być może zaproponowanie innych rozwiązań teoretycznych.

Szczególnie wartościowe wydaje się poddanie pod rozwagę zjawiska, które określa się mianem „przełomu technologicznego” epok neolitu i brązu (Kopacz, Valde-Nowak 1987). Materiały krzemienne tego czasu są silnie zróżnicowane morfologicznie. Poważny problem stwarza niehomogeniczność inwentarzy. Zabytki osadowe pochodzące z różnych okresów często są ze sobą przemieszane. Niepodważalna jest wczesnobrązowa chronologia stanowisk o charakterze sepulkralnym, nawet pomimo obecności w grobach redepozytów (m. in. Kadrow, Machnikowie 1992; Baczyńska 1993). Cmentarzyska wczesnobrązowe są jednakże dość nieliczne. Uważa się także, iż społeczności wczesnej epoki brązu (w przeciwieństwie do neolitycznych) produkując narzędzia krzemienne bazowały na lokalnym surowcu. Wyjątek stanowią zaawansowane technologicznie formy z dwustronną obróbką powierzchniową, szczególnie w typie płoszczy i sierpów (Kadrow 1995b, 241-245). Wyroby te, choć są znaleziskami w większości pozbawionymi kontekstu archeologicznego (Libera 2001, 78, 92), świadczą niemniej jednak o wysokich umiejętnościach ich wytwórców (Kopacz, Valde-Nowak 1987, 78). Surowiec, z których je wykonano, pochodzi ze złóż odległych nawet o setki kilometrów. Co więcej określanie przynależności chronologicznokulturowej stanowisk eksploatacji górniczej nastręcza zawsze wielu trudności. Brak jest bowiem odpowiednich metod datowania tego typu zespołów (Budziszewski 1998, 290). 
Powyższa teza wskazuje na trudności przy prawidłowej identyfikacji materiałów krzemiennych pochodzących z wczesnej epoki brązu. Problem ten wymaga szerszego omówienia, co też będzie tematem niniejszego artykułu. Ponadto postawiono sobie za cel zaproponowanie pewnej koncepcji teoretycznej odnoszącej się do wybranych elementów krzemieniarstwa wczesnobrązowego w Małopolsce. Jednocześnie, chcąc nadać artykułowi interdyscyplinarny ton, starano się ukazać w rozważaniach wizję człowieka i społeczeństwa z perspektywy psychologii społecznej.

\section{ZAKRES PRZESTRZENNY I ZAŁOŻENIA TEORETYCZNE}

Zakres przestrzenny rozważań ogranicza się do obszaru Polski południowo-wschodniej, głównie strefy lessów. Obejmuje on w szczególności Wyżynę Małopolską, LubelskoLwowską oraz zachodnią część wyżyny Wołyńsko-Podolskiej (Kondracki 2002). Obszar ten odpowiada w dużej mierze terytorium historycznej Małopolski. Mając na uwadze właściwy odbiór prezentowanych treści, należy podkreślić, iż przedmiotem zainteresowania będzie głównie społeczność kultury mierzanowickiej. Tym samym zagadnienia związane z kulturą strzyżowską będą akcentowane tylko częściowo lub zostaną całkowicie pominięte.

Aby uprawomocnić tezy stawiane w dalszej części pracy, chciałbym zwrócić uwagę na elementy decydujące o kształcie danej wytwórczości krzemieniarskiej. Przyjmuję, iż charakter krzemieniarstwa w danym okresie i na określonym obszarze jest wypadkową stopnia intensywności poszczególnych z poniżej wymienionych czynników. Pierwszym z nich jest potrzeba, jednakże w ujęciu nie tylko ekonomicznych możliwości stosowania określonych narzędzi. Pojęcie to będzie obejmować także zapotrzebowanie na wyroby prestiżowe (Banning 2000, 141). Drugi z elementów to kwalifikacje wytwórców narzędzi. Należy je rozumieć jako fizyczne zdolności motoryczne człowieka, jego umiejętności, doświadczenie oraz wiedza. Elementy te są wyrazem możliwości i wydajności (Pelegrin 1990, 116-125; Banning 2000, 141). Ważnymi czynnikami determinującymi kształt wytwórczości krzemieniarskiej mogą być ponadto lokalne uwarunkowania surowcowe (Apel 2001, 30) oraz tradycje kulturowe.

Stosując w artykule pojęcie „narzędzie”, mam na myśli jego morfologię. Nie odnoszę się tym samym do walorów użytkowych wyrobów, chyba że zaznaczam to wyraźnie w tekście. W badaniach nad krzemieniarstwem nie postrzegam pojęć „technologia” i „technika”. jako synonimów. „Technologia” będzie stanowić obszerny koncept myślowy prowadzący do określonego sposobu redukcji bryły krzemiennej. Będzie on obejmował zarówno wiedzę jak i doświadczenie w zakresie wszelkich działań związanych z teorią i praktyką krzemieniarską. „Technika” odnosić się będzie natomiast do konkretnych sposobów obróbki (np. z użyciem twardego, miękkiego tłuka czy nacisku) (por. Andrefsky 1998, 11-12). 


\section{HISTORIA I STAN BADAŃ}

Szczegółowa historia badań nad materiałami krzemiennymi z wczesnej epoki brązu w Małopolsce była już prezentowana w literaturze (Kopacz, Valde-Nowak 1987, 58-62). Uwagi dotyczące historii kształtowania się wiedzy o krzemieniarstwie tego okresu z uwzględnieniem wybranych regionów Europy Środkowej przedstawili K. Jażdżewski (1981, 15-53) oraz J. Kopacz (2001, 37-38). Inni badacze ukazali stan badań nad wyraźnie wyróżniającymi się formami narzędziowymi wiązanymi z wczesną epoką brązu - wyrobami z bifacjalną obróbką powierzchniową (Borkowski 1987; Bargieł, Libera 1997, 145-146; Borkowski, Kowalewski 1997; Libera 2001, 12-22, 46-50). Kilka znaczących prac nie ukazało się drukiem do dnia dzisiejszego. Dotyczy to podsumowania badań krzemieniarstwa w regionie osadniczym w Iwanowicach (Kopacz 1978) oraz materiałów pochodzących z wczesnobrązowych cmentarzysk Wyżyny Sandomierskiej (Bąbel 1987). Dwie inne istotne prace opublikowano w formie skróconej - w artykułach. Poruszono w nich problematykę technologii produkcji i morfologii grocików sercowatych (Borkowski 1987) oraz zaprezentowano przegląd inwentarzy krzemiennych przełomu neolitu i epoki brązu z Wyżyny Środkowomałopolskiej (Budziszewski 1991). Pracę o podobnym charakterze do tej ostatniej, ale $\mathrm{w}$ odniesieniu do materiałów z górnego odcinka Wieprza, opublikował B. Balcer (1991; także Balcer et al. 2002).

Już od początku XX-tego wieku badacze dysponując licznymi znaleziskami próbowali usystematyzować wiedzę o odkrywanych materiałach kamiennych, przedstawiając propozycje co do ich chronologii i przynależności kulturowej. Pierwsze próby wyodrębnienia materiałów krzemiennych (wczesnobrązowych w dzisiejszym rozumieniu) jako osobnej kategorii zabytków sięgają czasów sprzed I wojny światowej i działalności L. Kozłowskiego (1913; 1917). Badacz ten, na bazie przeprowadzonych wykopalisk archeologicznych w okolicach Iwanowic, jako pierwszy zwrócił uwagę na specyfikę tych materiałów wyróżniając tzw. „przemysł iwanowicki” (Kozłowski 1913, 40). Inwentarz wymienionej jednostki stanowiły wówczas wymieszane materiały znane dziś jako neolityczne i wczesnobrązowe, przy dominującej liczbie tych ostatnich. Późniejsze interpretacje tego samego uczonego określają wczesnobrązowe, małopolskie materiały krzemienne jako przynależne do ówcześnie wyszczególnionej tzw. „kultury mikrolitycznej” (Kozłowski 1923, 160), a następnie, po modyfikacji, „kultury neolitu mikrolitycznego” (Kozłowski 1924, 24) oraz „przemysłu/kultury nadbużańskiego(-ej)" (Kozłowski 1924, 85-90).

Niezwykle ważne okazały się badania osady oraz cmentarzyska w Mierzanowicach przeprowadzone w latach 1936-1938. W trakcie wykopalisk pozyskano liczne wyroby kamienne (Salewicz 1937). Niemal równocześnie prowadzono prace wykopaliskowe na Wołyniu oraz w Strzyżowie, gdzie odkryto kilka innych stanowisk zawierających materiał wczesnobrązowy - m.in. Torczyn (Fitzke 1938; 1975) oraz Sapanów (K.J. 1936; Podkowińska 1936; 1960). 
Badania przeprowadzone w czasach zarówno przed jak i powojennych pozwoliły klasyfikować wyroby posiadające cechy „makrolityczne” i obróbkę bifacjalną, w tym także siekiery dwuścienne, jako przynależne do kultur przełomu neolitu i epoki brązu Małopolski (por. Salewicz 1937, 58-59; Kopacz, Valde-Nowak 1987, 60).

Narzędzia odłupkowe zaczęto postrzegać jako wyroby charakterystyczne dla tego okresu (m. in. Machnik 1967). W ten sposób zarysowała się dwubiegunowość rozwoju krzemieniarstwa przełomu epok - z jednej strony złożone pod względem technologicznym formy bifacjalne z retuszem powierzchniowym, z drugiej zwykłe odłupki, często nawet pozbawione intencjonalnego retuszowania (por. Balcer 1971, 63-68).

Wartościowe dla poszerzenia dotychczasowej wiedzy o krzemieniarstwie wczesnej epoki brązu były prace wykopaliskowe kompleksu osadniczego w Iwanowicach (Machnikowie 1973). Liczne wyroby kamienne dały pełniejszy obraz tego rodzaju wytwórczości. Wstępnego opracowania materiałów dokonał Kopacz (1976), który tym samym określił charakter typowo wczesnobrązowego krzemieniarstwa w Małopolsce. Ponadto opracowano zabytki krzemienne z osady w Mierzanowicach (Balcer 1977).

Warto nadmienić, iż inne materiały, dziś znane jako wczesnobrązowe, dzięki swojej specyfice były niekiedy wiązane ze starszą epoką kamienia (Schild 1971, 42-48). Czasem w ogóle nie podejmowano się ustalania chronologii tego typu inwentarzy (Chmielewska 1973). Tyczy się to odkrytych stanowisk o charakterze wydobywczym: Polany II i Polany Kolonie II. Weryfikacja tych poglądów nastąpiła jeszcze w latach 70. dwudziestego stulecia (Schild et al. 1977; por. także uwagi Budziszewski 2008, 36-37).

Zmiana kształtu wytwórczości krzemieniarskiej, która nastąpiła na przełomie epok, zyskała miano „rewolucji technologiczno-narzędziowej” (Schild et al. 1977, 96; por. także Lech 1982/1983, 53). Za typowe cechy dla tego zjawiska uznano „makrolityzację” niektórych narzędzi, zanikanie technologii wiórowej, wzrost znaczenia technologii rdzeniowej oraz powierzchniową obróbkę narzędzi (Kopacz, Valde-Nowak 1987, 79).

Ważne miejsce w historii badań nad zabytkami kamiennymi w Małopolsce zajmują badacze Kopacz i Valde-Nowak, którzy dokonali zbiorczej analizy krzemieniarstwa wczesnobrązowego w tym regionie, kontrastując je względem neolitycznych inwentarzy (Kopacz, Valde-Nowak 1987). Badacze odnieśli się przede wszystkim do gospodarki surowcowo-narzędziowej, syntetyzując dotychczasową wiedzę, a także wprowadzając nowe, oryginalne tezy. Uznali oni społeczności wczesnej epoki brązu za samowystarczalne ekonomicznie pod względem surowcowym (Kopacz, Valde-Nowak 1987, 75). Wprowadzili oni do literatury termin „narzędzia konwencjonalne”, oznaczający wysokiej jakości formy narzędziowe obrabiane bifacjalne, charakterystyczne dla wczesnej epoki brązu (Kopacz, ValdeNowak 1987, 78). Zaliczono się do nich głównie płoszcza, sierpy, grociki, a także siekiery. Badacze ci dokonali geograficznego rozróżnienia inwentarzy. Zauważyli, iż zespoły pochodzące z lessów małopolskich, odznaczających się bardzo wysokim potencjałem ekonomicznym dla społeczeństw rolniczych, wykazują najwięcej cech „rewolucji technologicznonarzędziowej”. Występowanie (lub nie) „narzędzi konwencjonalnych” w danym regionie 
Małopolski tłumaczono jakością dostępnego surowca, którego było pod dostatkiem na Wołyniu (krzemień wołyński) i Sandomierszczyźnie (krzemień ożarowski i niektóre rodzaje krzemienia czekoladowego) (Kopacz, Valde-Nowak 1987, 79). Ponadto zauważono, iż swoisty kanon procesu wytwórczego, mający swoje źródło w badaniach przede wszystkim zespołów paleolitycznych, obrazujący model redukcji bryły krzemiennej w kierunku uzyskania pożądanego narzędzia, uległ znaczącej zmianie u schyłku neolitu i w początkach epoki brązu. Świadczy o tym duża ilość nieregularnych form odłupkowych, często nieretuszowanych, które równie dobrze mogły pełnić funkcje użytkowe (por. też Lech 1997, 237-249). Według autorów opracowania „[...] podstawowym warunkiem powodzenia w badaniach zmiany wytwórczości krzemieniarskiej zachodzącej na przełomie epok nie jest bazowanie na szczegółowej, traktowanej uniwersalnie liście cech czy typów artefaktów, lecz zrozumienie nowej koncepcji przekształcania surowca w narzędzie, koncepcji odmiennej niż w okresach poprzednich" (Kopacz, Valde-Nowak 1987, 82). Terminy odpadek, rdzeń czy narzędzie uznano w przypadku inwentarzy wczesnobrązowych za bardzo niejednoznaczne (Kopacz, Valde-Nowak 1987, 82). Opracowanie Kopacza i Valde-Nowaka jest przełomowe, gdyż badacze zrezygnowali z klasycznego „wyliczenia” typowych form artefaktów i ich opisu. Podjęli oni próbę rozwiązania konkretnych problemów badawczych dotyczących gospodarki i społeczeństwa.

Istotny kierunek badań dotyczył odtworzenia sposobów pozyskiwania surowca krzemiennego przez społeczności wczesnobrązowe. Badacze zaprezentowali monografie następujących stanowisk wydobywczych: Polany Kolonie II (Schild et al. 1977), Polany II (Chmielewska 1988), Wierzbica „Zele” (H. i J. Lech 1984), Tomaszów I (Schild et al. 1985) oraz rezerwat „Krzemionki” (Borkowski et al. 1989). Początkiem lat 80-tych XX stulecia Lech sporządził syntetyczne opracowanie, w którym scharakteryzował jednostki eksploatacyjne (rodzaje jam, szybów) surowców krzemiennych (1981, 20-33). Gruntownego przeglądu krzemiennych materiałów górniczych oraz ich klasyfikacji jako zespołów wczesnobrązowych dokonał J. Budziszewski (1998). Obok stanowisk eksploatacji górniczej wyróżniono także miejsca przetwórstwa surowców krzemiennych, gdzie obrabiano pozyskany surowiec, produkując liczne zaczątkowe formy siekier i sierpów bifacjalnych (m. in. Schild et al. 1977, 103; Lech 1982/1983, 71-77; Budziszewski 1998, 286-298). W tym ujęciu końcowa obróbka mogła być dokonywana w osadzie macierzystej górników (Schild et al. 1977, 103). W powyższych badaniach podkreślane były często takie aspekty sposobów wydobycia surowca jak korzystanie z szybów, zbieranie surowca z powierzchni w okolicy kopalni czy efektywność wykonywanej pracy. Opinie badaczy dotyczące eksploatacji surowca krzemiennego podsumował S. Kadrow (1995a, 76-82). Badacz ten zestawił ze sobą dwubiegunowość wytwórczości krzemieniarskiej w Małopolsce. Uwypuklona została skłonność populacji wczesnobrązowych do wytwarzania tzw. „narzędzi konwencjonalnych” z krzemienia wysokiej klasy, pochodzącego z oddalonych wychodni. Zostało to skontrastowane z jednoczesną tendencją tych samych społeczności do zbierania surowca krzemiennego z najbliższej okolicy (Kadrow 1995a, 76-82, por. także Kadrow 1995b, 241-245). 
Materiały krzemienne coraz częściej stawały się ważnym źródłem interpretacji gospodarki i jej zmienności we wczesnej epoce brązu. Zobrazował to Kadrow na przykładzie mikroregionu osadniczego w Iwanowicach. Badacz uznał go za typowy dla społeczności wczesnobrązowej z Małopolski pod względem zapotrzebowania surowcowego i narzędziowego (Kadrow 1995a, 80).

Osobna kwestia dotyczy wyrobów z dwustronną obróbką powierzchniową. Występowanie form bifacjalnych odnotowane zostało praktycznie w całej Europie wczesnej epoki brązu (por. uwagi van Gijn 1988, 2010; Lech 1997, 237-249; Apel 2001; Kopacz 2001; Libera 2001). W literaturze przeważają opinie, że formy te pełniły wówczas szczególną rolę, głównie pozautylitarną (m. in. Kadrow 1995a, 80; Olausson 2000, 128; Apel 2001, 330). Inne badania potwierdzają natomiast funkcje użytkowe tych wyrobów (Bąbel, Budziszewski 1978; Balcer, Schild 1978a; ci sami 1978b; ci sami 1980). Wytwory krzemienne stały się poważnym materiałem poznawczym, na bazie którego wykazywać można funkcjonowanie w społeczeństwach wczesnobrązowych władzy i prestiżu (Kadrow 1995a, 93; ten sam 2001, 160-161; Olausson 2000, 128; Apel 2001, 330). Choć typowa społeczność mierzanowicka obyłaby się ekonomicznie bez tego rodzaju prestiżowych przedmiotów, to wytwory te mogły być społecznie cenione jako przedmiot dalekosiężnej wymiany (Kadrow 1995a, 93). Według Kadrowa wymiana tego typu „miała zapewne charakter instytucjonalny”, a jej mechanizmy „wpływały na organizację, stabilizację lub ewolucję makrostruktur społecznych”. Ponadto przedmioty wymiany, jak i mechanizmy ich cyrkulacji mogły służyć „zachowaniu władzy i podtrzymaniu posiadanego prestiżu społecznego” (Kadrow 1995a, 93).

W ostatnich latach prace dotyczące krzemieniarstwa wczesnobrązowego w Małopolsce mają typowo kulturowo-historyczny charakter. Zasadniczą rolę odgrywają w nich podejścia morfometryczne oraz ewolucjonistyczne. W publikacjach tych uwaga skupiona jest na rozbudowanej analizie stylistyczno-typologicznej materiału zabytkowego (Bargiel, Libera 1997; Borkowski, Kowalewski 1997; Libera 2001). Zjawiska społeczno-kulturowe interpretowane są jako rezultat docierania do Małopolski niektórych elementów kultury materialnej z wysoko rozwiniętych pod względem kulturowym terenów Kotliny Karpackiej (Kopacz 2001).

\section{CHARAKTERYSTYKA ŹRÓDEK}

\section{a. Cmentarzyska}

Szarbia jest pierwszym z wyróżnionych stanowisk sepulkralnych (Baczyńska 1993). Cmentarzysko należy łączyć z dwoma fazami chronologicznymi kultury mierzanowickiej - klasyczną i późną (Baczyńska 1993, 7). Na stanowisku odnotowano ogółem 79 wyrobów krzemiennych - 50 odpadków, 28 narzędzi oraz 1 łuszczeń (Baczyńska 1993, 27). Ponieważ stwierdzono silne zaburzenia stratygrafii, wspomniany materiał może stanowić neolityczne redepozyty. Okoliczność ta pozwoliła uznać za wczesnobrązowe tylko niektóre dary 
grobowe - grociki sercowate (19 szt.) oraz dwa inne narzędzia - fragment przekłuwacza i nóż. W zdecydowanej większości wyroby te wykonano z krzemienia jurajskiego (Baczyńska 1993, 27).

Kolejne bardzo bogate cmentarzysko odkryto w Mierzanowicach (Salewicz 1937). Ujawniło ono wiele cennych zabytków krzemiennych. Niestety pokaźna ich ilość pochodzi z warstwy zniszczonej przez działalność rolniczą. Na stanowisku odkryto ponad 300 grocików sercowatych - (Salewicz 1937, 46). W grobach z Mierzanowic warto odnotować znaczną ilość sierpów (łącznie 28 okazów) (Salewicz 1937, 50, 53, 56, 57) oraz kilka noży (Salewicz 1937, ryc. 12-13: 13a; ryc. 17: d) i siekierek o soczewkowatym przekroju (Salewicz 1937, ryc. 17: e, ryc. 20: d, 24: a, c, d). Surowcowo przeważa krzemień ożarowski (Salewicz 1937, 50).

Godne wyróżnienia są niektóre ze stanowisk grobowych, które dostarczyły okazów płoszczy (por. Bargieł, Libera 2005). W pierwszej kolejności należy wymienić stanowisko 3 oraz 4 w Czerniczynie, gdzie natrafiono na kilka tego typu wyrobów o różnym kształcie (Libera 2001, 77). Płoszcza w kontekście grobowym znane są także m. in. z takich stanowisk jak: Siekierzyńce, Sitno, Strzyżów, Miernów (Libera 2001, 77), Wojciechowice (Kadrow, Machnik 1997, 85), Złota (Libera 2001, 82) oraz Raciborowice-Kolonia, stan. II (Libera 2001, 81). Okazy te datowane są ogólnie na wczesną epokę brązu (por. Budziszewski 1991, 196), choć niektóre z nich utożsamiane są raczej z kulturą strzyżowską. Kontekst płoszcza znanego z grobu 55 z Wojciechowic pozwala sądzić, iż produkcja tych narzędzi mogła utrzymać się nawet do fazy późnej kultury mierzanowickiej (Libera 2001, 81).

Oprócz najliczniej reprezentowanych sierpów z cmentarzyska w Mierzanowicach, zabytki te znane są także w mniejszej ilości z kilku innych stanowisk o charakterze sepulkralnym. Odkryto je między innymi w: Złotej „Nad Wawrem”, Wojciechowicach, stan. 1, Orliskach Sokolnickich, stan. 1, a także w Trześni. Sierpy ujawnione na tych cmentarzyskach wykonano głównie z krzemienia ożarowskiego, nieliczne z krzemienia czekoladowego i świeciechowskiego (Libera 2001, 92-93).

Należy odnotować współwystępowanie sierpów z wyrobami miedzianymi oraz charakterystyczną ceramiką w grobach z cmentarzysk w Mierzanowicach i Złotej. Fakt ten upoważnia do datowania ich na fazę późną kultury mierzanowickiej. Na chronologię taką wskazuje także ewidentny brak tych wytworów we wcześniejszych fazach rozwoju tej kultury (por. Kadrow, Machnik 1997, 83; Kadrow 2000, 142; Libera 2001, 93-94).

\section{b. Osady}

Dla omawianej problematyki kluczowe znacznie ma kompleks osadniczy na Babiej Górze w Iwanowicach. Wczesnobrązowe wyroby krzemienne z tego stanowiska opracował szczegółowo Kopacz (1978). Materiał pochodzi w ogromnej większości z wypełnisk obiektów określonych na podstawie ceramiki jako przynależne do kultury mierzanowickiej (Kopacz 1976, 88-90). Wyróżniono ponad 30000 okazów, z których większość została wykonana z krzemienia jurajskiego odmiany B2. W inwentarzu znalazły się także wytwory z innych 
miejscowych skał krzemionkowych (czertów). Sporadycznie wystąpiły wyroby z krzemienia czekoladowego, obsydianu oraz wytwory z krzemienia wołyńskiego i pasiastego krzemionkowego (Kopacz 1978 za Valde-Nowak 1987, 63). Pełna struktura inwentarzowa została zaprezentowana w oddzielnym artykule - stanowi ona jednak niewielki wskaźnik całości materiałów z Iwanowic (Kopacz 1976). Kopacz uznał stanowisko za typowo pracowniane wskazując na bardzo wysoki procent odłupków i odpadków (ponad 95\%) (Kopacz 1976, 104). Surowiec został opisany jako słaby jakościowo, a formy rdzeniowe jako niestaranne (Kopacz 1976, 91-92). Zwrócono uwagę na brak możliwości stosowania na szerszą skalę złożonych technologii produkcji, takich jak wiórowa redukcja bryły krzemiennej (Kopacz 1976, 89-90). Pośród narzędzi rdzeniowych wyróżniono siekiery dwuścienne ze zwężonym obuchem, tzw. soczewkowate (17 okazów wykończonych - szlifowanych i 9 niewykończonych). Wykonywano je najczęściej ze słabo zsylifikowanego krzemienia (tzw. petrosileksu), często zbliżonego wyglądem do wapienia (Kopacz 1976, 96-97). Autor opracowania informuje o obecności w inwentarzu znacznej liczby drapaczy oraz form typologicznie zbliżonych do środkowopaleolitycznych (formy nożowate i tylcowe). Pozostałe rodzaje wyrobów odgrywają rolę marginalną, a być może stanowią one obcą kulturowo domieszkę (Kopacz 1976, 97-99). Zaprezentowany przegląd materiałów można poszerzyć jedynie o niewielką ilość grocików sercowatych znalezionych poza obiektami osadowymi (Kopacz, Valde-Nowak 1987, 63). Ponadto warto odnotować obecność płoszcza odkrytego w jamie nr 83 (Kadrow, Machnik 1997, 67-68).

Należy zwrócić szczególną uwagę na wielofazową osadę kultury mierzanowickiej w Mierzanowicach, z której pochodzi bogaty zbiór wyrobów krzemiennych. Autorem ich opracowania jest Balcer (1977). W inwentarzu stwierdzono około 1200 zabytków wykonanych przede wszystkim z krzemienia pasiastego krzemionkowskiego (65,4\%), ale także czekoladowego $(16,4 \%)$ oraz świeciechowskiego (9,7\%). Nielicznie reprezentowany jest krzemień ożarowski, bałtycki i wołyński (Balcer 1977, 193). Pod względem technologicznym dominuje tendencja do odłupkowej redukcji bryły krzemiennej. Technologia wiórowa, jak i łuszczniowa, są raczej słabo reprezentowane w inwentarzu (Balcer 1977, 203). Wśród wytworów krzemiennych dominują pozostałości produkcyjne oraz półsurowiec (91\%) (Balcer 1977, 197). Podstawową i najbardziej charakterystyczną grupą wyrobów na stanowisku są zaczątkowce i półwytwory siekier dwuściennych (67 okazów) (Balcer 1977, 198), a także wyroby określone jako zgrzebła i obustronne formy nożowe (Balcer 1977, 199-200). Zauważono przy tym znikomą ilość wyrobów charakteryzujących się obustronnym retuszem powierzchniowym (dwa grociki oraz jedno płoszcze) (Balcer 1977, 200). W obiektach mierzanowickich ujawniono także ewidentne neolityczne redepozyty w postaci czworościennych siekier kultury amfor kulistych (Balcer 1977, 193). W literaturze pojawiają się głosy krytyczne kwestionujące uznawanie materiałów z osady w Mierzanowicach za pełnowartościowe źródło - między innymi z powodu przemieszania artefaktów wczesnobrązowych z neolitycznymi (Budziszewski 1991, 196). Niemniej jednak nie ulega wątpliwości, że wielofazowość osadnictwa mierzanowickiego stwierdzona w toku badań stanowiska oraz 
znaczna liczba artefaktów pozwalają na szeroki ogląd wytwórczości krzemieniarskiej omawianej społeczności.

Innym wyszczególnionym stanowiskiem osadowym są Opatkowice. Materiały krzemienne z tego stanowiska zostały opracowane przez Valde-Nowaka (2000). Uwagę zwraca szczególnie bogaty zespół z jamy nr 4, uznany za wczesnobrązowy (Valde-Nowak 2000, 305). Autor wskazuje na człon pracowniany zespołu. W jego obrębie wyróżnia tłuczki, rdzenie oraz odłupki, przy niewielkim udziale tych ostatnich (Valde-Nowak 2000, 317). $\mathrm{W}$ inwentarzu brak jest takich form jak płoszcza, sierpy, siekiery czy grociki. Wysoki jest natomiast wskaźnik form nożowatych, tylcowych (Valde-Nowak 2000, 317) oraz łuszczniowych (Valde-Nowak 2000, 311). Zidentyfikowano także nietypowe formy - trapezowate segmenty o piłkowato uformowanych krawędziach, znanych z kultury unietyckiej i kultury Otomanii (Valde-Nowak 2000, 318).

\section{c. Stanowiska eksploatacji krzemienia}

Materiały pochodzące ze stanowisk górniczych wymagają osobnego komentarza. Pierwszy wyróżniony zespół zabytków krzemiennych pochodzi ze stanowiska „Za Garncarzami” w rejonie Ożarowa. Liczył on 4200 okazów i zawierał 21 form rdzeniowych. Wydzielono wśród nich gracę, pik/łuszczeń, 5 zgrzebeł, 2 rdzenie, 3 amorficzne formy rdzeniowe, 9 zaniechów lub fragmentów zaczątkowców dużych narzędzi bifacjalnych (4 z nich wiążą się z wytwarzaniem noży sierpowatych) oraz 2 siekiery. Niektóre formy rdzeniowe noszą ślady przegrzewania (Budziszewski 1998, 291). Drugi zespół z tego stanowiska zawierał 2300 zabytków krzemiennych. W inwentarzu wyszczególniono 14 form rdzeniowych (2 rdzenie, 8 zaniechów lub fragmentów zaczątkowców dużych narzędzi bifacjalnych, w tym dwóch noży sierpowatych) (Budziszewski 1998, 291).

Jedno ze skupisk krzemienia czekoladowego nad rzeką Kamienną "Wzgórze Kruk" (Budziszewski 1987) również dostarczyło interesujących znalezisk. Odkryto pracownie krzemieniarskie związane z wytwarzaniem odłupków amorficznych z szerokoodłupniowych rdzeni eksploatowanych bez wcześniejszego przygotowania bryły, a w końcowych fazach łuszczniowo. W pracowniach tych stwierdzono obecność relatywnie licznych $\left(0,5^{-}\right.$ 1\%) wytworów z krzemienia ożarowskiego - w tym fragmentu zaczątkowa noża sierpowatego (Budziszewski 1987 za Budziszewski 1998, 295-296). Dane te pozwalają łączyć stanowisko z wczesną epoką brązu.

Nieliczne zaniechy lub fragmenty zaczątkowców płoszczy znane są z „Polan Kolonii II” (Schild et al. 1977), „Polan II” (Chmielewska 1973), noży sierpowatych z „Polan Kolonii II” (Schild et al. 1977), „Polan II” (Chmielewska 1988), „Nowego Rachowa” (Bargiel, Libera 1996), a siekier dwuściennych ze stanowisk „Polany II” (Chmielewska 1973), „Polany Kolonia” II (Schild et al. 1977), „Zele” (Młynarczyk 1983), „Nowy Rachów” (Bargieł, Libera 1996). Zabytki te to zwykle tylko znaleziska powierzchniowe, bez kontekstu archeologicznego. Na opisanych pokrótce stanowiskach górniczych pozyskiwano krzemień czekoladowy, świeciechowki/gościeradowski, pasiasty i ożarowski (Budziszewski 1998, 288). 
Interesujących uwag nawiązujących do kwestii pozyskiwania surowca do produkcji grocików sercowatych dostarcza Budziszewski (1991; ten sam 2008, 38-39). Otóż okazuje się, iż najliczniejszymi znaleziskami na powierzchni punktów eksploatacji krzemienia czekoladowego są formy odłupkowe. Ze względu na ich cechy metryczne nie mogły one stanowić raczej materiału produkcyjnego dużych narzędzi bifacjalnych. Wytwarzanie tych odłupków można łączyć z zapotrzebowaniem społeczności wczesnej epoki brązu na półprodukty wysokiej jakości, przekształcane w efekcie w grociki (por. Budziszewski 2008, 38-39, 93).

\section{d. Znaleziska luźne}

Z terenu Małopolski pochodzi szereg płoszczy i sierpów odkrytych bez kontekstu archeologicznego. Stanowią one 90\% wszystkich tego typu form poznanych do tej pory (Libera 2001, 78, 92). Narzędzia z dwustronną obróbką powierzchniową odkryte w dorzeczu Sanu skatalogował Libera. Wyszczególniono tam ponad 110 znanych płoszczy i sierpów (Libera 2010, 21-27).

\section{GŁÓWNE CECHY KRZEMIENIARSTWA WE WCZESNEJ EPOCE BRAZZU W MAŁOPOLSCE}

W świetle powyższych źródeł możliwa jest prezentacja podstawowych cech krzemieniarstwa wczesnej epoki brązu dla omawianej strefy geograficznej. Charakterystyka ta uwzględnia podział na gospodarkę surowcową, strukturę narzędziową oraz stosowane technologie i techniki.

\section{a. Gospodarka surowcowa}

Dominuje wykorzystywanie surowców z możliwie najbliższych okolic. Z przeprowadzonych studiów wynika jednoznacznie, iż charakter eksploatacji górniczej jest we wczesnej epoce brązu zupełnie odmienny niż w okresach starszych. Zasadniczą strategią i celem tych społeczności w zakresie pozyskiwania surowca nie jest udoskonalanie technik górniczych i sięganie po coraz głębiej położone bryły surowca. Zamiast tego wybierane zostają przeważnie optymalne rozwiązania logistyczne oparte na perfekcyjnym rozpoznaniu złóż łatwo dostępnych (Budziszewski 1991, 197). Skały ze złóż odległych odgrywają przy tym rolę drugorzędną, o ile nie marginalną (por. Kadrow 1995b, 241-245). Uwagę zwraca także znaczna rola lokalnie dostępnych skał o mniejszej zawartości krzemionki oraz skał niekrzemionkowych (Kopacz, Valde-Nowak 1987, 76). Formy bifacjalne wytwarzane były tylko z wysokiej klasy surowców - głównie z krzemienia wołyńskiego, w mniejszym stopniu z surowca jurajskiego, świeciechowskiego, czekoladowego i ożarowskiego (Libera 2001, 77-82, 92-95; por. także Libera 2010, 4, 16). Niekiedy różnicowano dobór surowca w odniesieniu do produkcji określonych form z dwustronną obróbką (por. Budziszewski 1991, 195-196). 


\section{b. Technologia i technika}

Wczesnobrązowe wyroby krzemienne z Małopolski odznaczają się wyraźną różnorodnością technologiczną. W inwentarzach odnotowywana jest obecność zarówno form odłupkowych jak i rdzeniowych (Kopacz 2001, 39). Ponadto uważa się, iż stopień tożsamości morfologicznej form wyjściowych i odpadków jest bardzo wysoki (por. Kopacz, ValdeNowak 1987, 78). Wyraźnie zaznacza się tendencja do odłupkowego rdzeniowania (ryc. 3). Rolę technologii wiórowej można uznać za mało znaczącą wśród społeczności wczesnobrązowych na małopolskich lessach (Lech 1982/1983, 53; Schild et al. 1985, 96; Kopacz, ValdeNowak 1987, 79; Budziszewski 1991, 206). W niektórych wczesnobrązowych inwentarzach uwagę zwraca znaczny udział produktów łuszczniowych (m. in. Kraussowie 1971: ryc. 7c; Valde-Nowak 2000, 311). Wytwory te wiązać się mogą nie tylko z chęcią oszczędnego rdzeniowania. Mogły one pełnić równie dobrze funkcję uniwersalnych narzędzi (Budziszewski 1991, 201). Valde-Nowak stawia hipotezę bardziej ogólną o nieuwzględnianiu standardów (kształt, wymiary półsurowca) i możliwości używania przez społeczności wczesnobrązowe niemal wszystkich dostępnych form (Valde-Nowak 2000, 317). Powyższe sugestie zostaną wkrótce w pewnym zakresie zweryfikowane przez autora niniejszego artykułu. Prowadzone są bowiem kompleksowe analizy inwentarzy mierzanowickich pod kątem obecności na zabytkach mikrośladów użytkowania.

We wczesnej epoce brązu w Małopolsce bardziej powszechne stają się inne niż samo łupanie sposoby (techniki) kształtowania bryły - gładzenie (Piątkowska, Dobrzyński 2011, 113) i łamanie (Kopacz 2001, 39). W klasycznych inwentarzach wczesnobrązowych brak jest typowych dla neolitu makroskopowych śladów obróbki krzemienia. Świadczy o tym nikły udział technik związanych z użyciem pośrednika rogowego, nacisku czy uderzenia miękkim tłukiem - drewnianym lub rogowym (Migal 1997, 141).

\section{c. Narzędzia}

Model redukcji bryły krzemiennej ukierunkowany na pozyskiwanie odłupków czy wiórów o określonych, pożądanych przez wytwórców formach (por. Cotterell, Kamminga 1987), uległ pewnemu załamaniu we wczesnej epoce brązu (por. ryc. 4). Wiąże się to z ogólnym zanikaniem w inwentarzach cech typologicznych narzędzi (Lech 1982/1983, 53; Schild et al. 1985, 96; Kopacz, Valde-Nowak 1987, 79). Niektórzy badacze sugerują nawet, iż znaczna część użytkowanych wyrobów była obrabiana tylko doraźnie lub nie była obrabiana wcale (Kopacz 2001, 39; por. także Małecka-Kukawka 2001 dla inwentarzy neolitycznych). Pogląd ten, choć prawdopodobny, wiąże się niemniej z potrzebą przeprowadzenia analiz traseologicznych dla reprezentatywnych, wczesnobrązowych zespołów krzemiennych.

W przypadku osad widoczne jest ograniczenie wytwórczości krzemieniarskiej do wąskiego zestawu narzędzi, nawet pomimo usytuowania w pobliżu dogodnych złóż surowca (Kopacz 1976, 95; Kadrow 1995a, 80; Kadrow 1995b, 244). Wyraźny kontrast wobec tego stwierdzenia stanowi pojawienie się wytworów o bardzo wyraźnych cechach morfologicznych 
(bifacjalna obróbka powierzchniowa), świadczących o ich szczególnej funkcji oraz specjalnych kwalifikacjach wytwórców tych wyrobów. Wytwory te określono jako tzw. „narzędzia konwencjonalne" i wyróżniono wśród nich sierpy (Ryc. 5: 4, 5, 8; 6: 5-8), płoszcza (Ryc. 5: 1, 3, 6, 7), a także siekiery i grociki (Kopacz, Valde-Nowak 1987, 78). Zabytki te składano często jako dary grobowe oraz deponowano w skarbach (por. Kadrow 1995a, 80; Kopacz 2001, 39). Powszechnymi formami są grociki sercowate $\mathrm{z}$ łukowato podciętą podstawą (Ryc. 5: 2; 7), przypisywane często do kultury mierzanowickiej (Borkowski 1987, 161-167, ryc. 20). Uzyskuje się je, jak przekonuje Budziszewski, ewidentnie wskutek amorficznego rdzeniowania odłupkowego (Budziszewski 1991, 194; por. Ryc. 6: 9 oraz uwagi powyżej). W dużej grupie tych zabytków występuje wyraźnie intencjonalne ząbkowanie krawędzi (Borkowski, Kowalski 1997, 205-214). Grociki te odkrywane są często w mierzanowickich inwentarzach grobowych (Salewicz 1937; Baczyńska 1993). Jak się wydaje, nie należy ich jednak łączyć wyłącznie z tą kulturą (por. Borkowski 1997, 205-214).

Za bardziej powszechne w stosunku do wyróżnionych form bifacjalnych należy uznać dwuścienne siekiery soczewkowate. Wytwory te występują sporadycznie w inwentarzach kultury ceramiki sznurowej (Machnik 1966, 160; Włodarczak 2006, 20-28), szczególnie w późnych horyzontach tej kultury (Budziszewski 1991, 206). Typowe są one natomiast dla wczesnej epoki brązu w Małopolsce (por. Salewicz 1937, 58-59; Głosik 1968, 53; Kopacz 1976, 96-97; Balcer 1977, 198; Kopacz, Valde-Nowak 1987, 60). Budziszewski uznaje fakt pojawienia się dwuściennych siekier za zjawisko szczególne. Uderza bowiem swoista regionalizacja tego fenomenu związana z funkcjonowaniem różnych centrów produkcji siekier (szerzej Budziszewski 1991, 206). Warto wspomnieć, iż odłupki produkcyjne tych wyrobów niekiedy retuszowano (Budziszewski 1991, 204).

Zespoły wczesnobrązowe zawierają mniej lub bardziej liczne formy definiowane ogólnie jako zgrzebłowate oraz smuklejsze nożowate i tylcowe (Schild et al. 1977, 94; Balcer 1977, 199; Kopacz, Valde-Nowak 1987, 80; Budziszewski 1991, 194; Valde-Nowak 2000, 317). W inwentarzach pojawiają się sporadycznie rdzeniowe wyroby o kształcie pikowatym (Kopacz 1976, tabl. II: 9, III: 1; Machnikowie, Kaczanowski 1987, ryc. 13: 15, 16: 11), uważane często za narzędzia o charakterze górniczym. Swój udział zaznaczają także dość masywne drapacze (Kopacz 1976, tabl. III: 6-9) i przekłuwacze (Kopacz 1976, tabl. II: 7, 8, IV: 12). Zestaw narzędziowy uzupełniają tłuki kamienne.

Powyższa charakterystyka daje pewien obraz wczesnobrązowej wytwórczości krzemieniarskiej z Małopolski. Gospodarka surowcowa, technologia krzemieniarska oraz struktura narzędziowa wydają się być podobne w całej omawianej strefie. Zasięgi występowania charakterystycznych wyrobów (płoszczy i sierpów) nie nawiązują do granic kulturowych (Ryc. 1; 2). Obszary ich produkcji również nie odpowiadają wspomnianym granicom. Liczne pracownie płoszczy oraz sierpów mogły koncentrować się na granicy zasięgów kultury mierzanowickiej i strzyżowskiej (Kadrow 1995a, 82). Według ustaleń Libery obszar produkcji płoszczy i sierpów ogranicza się do terenów Wołynia - nad Styrem i Horyniem, w mniejszym stopniu Podola - nad Dniestrem (Libera 2010, 17). Dobrze widoczne jest, iż 
częstotliwość ich występowania skupia się w zachodniej części Małopolski i wyraźnie wzrasta z zachodu na wschód, począwszy od linii Wisłoki (por. Ryc. 1; 2).

Zaprezentowanej problematyce towarzyszy kilka innych wątpliwości wymagających omówienia. Po pierwsze należy przypuszczać, iż materiał pochodzący z cmentarzysk jest silnie wyselekcjonowany i nie odzwierciedla struktury narzędziowej, funkcjonującej w życiu codziennym społeczności wczesnej epoki brązu. Co więcej w grobach wczesnobrązowych licznie reprezentowane są neolityczne redepozyty (np. Szarbia). Podobna kwestia dotyczy materiałów z osad. Tam również materiały wczesnobrązowe przemieszane są z neolitycznymi w wyniku procesów podepozycyjnych. O ile narzędzia typowe dla późnego neolitu, takie jak na przykład siekiery czworościenne, są łatwe do wychwycenia (m.in. Bargieł 2002, 125), to więcej trudności nastręczają mniej charakterystyczne wyroby albo zwyczajny półsurowiec. Należy ponadto wziąć pod uwagę, iż znaleziska wytworów krzemiennych mogą stanowić materiał odpadkowy, nienadający się (w mniemaniu użytkowników) do dalszej pracy.

W przypadku znalezisk luźnych niepewna wydaje się chronologia płoszczy. Nie jest do końca jasne kiedy zaprzestano ich produkcji. Dużo łatwiejsze jest datowanie sierpów, kojarzonych na podstawie zwartych kontekstów grobowych zawsze z fazą późną kultury mierzanowickiej.

Trudne do jednoznacznej klasyfikacji kulturowo-chronologicznej są materiały pochodzące ze stanowisk wydobywczych. Bogate są one w liczne materiały o charakterze odpadkowym. W miejscu eksploatacji porzucane są nieraz półprodukty w postaci zaczątkowców, bądź zaniechów (Ryc. 6: 1-4, 9). Stanowiska tego typu zawierają często różnorodne artefakty pochodzące nawet $\mathrm{z}$ kilkuset albo kilku tysięcy kampanii górniczych, podczas których górnicy podejmowali nie tylko aktywność wydobywczą, ale także pracownianą i osadniczą (Budziszewski 1998, 287). Jak stwierdza Budziszewski „[...] próby określenia przynależności kulturowej użytkowników poszczególnych kopalń odwoływać się muszą do wymowy odkrywanych na stanowiskach górniczych materiałów pracownianych" (Budziszewski 1998, 290).

\section{TECHNOLOGIA, SPOŁECZEŃSTWO - PROBLEMATYKA WYSTĘPOWANIA NARZĘDZI BIFACJALNYCH ZE SZCZEGÓLNYM UWZGLĘDNIENIEM PŁOSZCZY I SIERPÓW}

Zasadniczym narzędziem badawczym w odniesieniu do wczesnobrązowych bifacjalnych wyrobów krzemiennych z Małopolski stała się metoda typologiczna. Podział na horyzonty kulturowo-chronologiczne płoszczy i sierpów zaproponował Libera (2001). Dokonano tego na podstawie analizy cech morfometrycznych tych wytworów (Libera 2001, ryc. 37: 125; ryc. 39: 129). Podejściu temu towarzyszy jednak kilka wątpliwości. Otóż tylko znikoma część zabytków pochodzi z pewnych grobów (płoszcza - około 7\%, noże sierpowate 
- blisko 4\%). Płoszcza stanowią niejednokrotnie jedyny element wyposażenia zmarłego (Libera 2001,132). Osiemdziesiąt siedem procent całego zbioru tych wytworów zarejestrowanych na ziemiach Polski i zachodniej Ukrainy to znaleziska luźne (Libera 2001, 77). Noże sierpowate w $91,77 \%$ są także znaleziskami bez kontekstu archeologicznego (Libera 2001, 92). Wśród badanych sierpów zauważono tylko niewielkie różnice w kształcie wierzchołka. Nie stwierdzono przy tym żadnych innych różnic morfologicznych i metrycznych (Bargiel, Libera 1997, 155). Ponadto rozbudowany system horyzontów funkcjonowania płoszczy i sierpów został utworzony w oparciu o szereg analogii „wtórnych”. Ustalano je na podstawie wydzielonych wcześniej typów, które zostały opracowane w nawiązaniu do nielicznych materiałów pewnych chronologicznie.

W związku z powyższym wydaje się słuszne uproszczenie podziału form bifacjalnych zaproponowanego przez Liberę (2001). Zasadne wydaje się uznanie I horyzontu występowania ptoszczy dla wczesnej epoki brązu bez rozbicia na podfazy. II horyzont można natomiast lączyć z wtórnym użyciem płoszczy przez ludność kultury trzcinieckiej. Uzasadnione jest także utrzymanie w mocy I horyzontu występowania sierpów bez podziału na podfazy, przesuwając jednocześnie ich datowanie ku fazie późnej kultury mierzanowickiej (por. Kadrow, Machnik 1997, 83; Kadrow 2000, 142). Potwierdzenie znajduje wydzielenie późnego horyzontu sierpów pótksiężycowatych dla kultury trzcinieckiej, a także łużyckiej (por. Bargieł et al. 1999). Należy jednak zauważyć, iż za kryterium rozróżnienia chronologicznego sierpów przyjmuje się w tym przypadku różnicę morfologiczną kształtu ich podstawy. Ponadto sierpy półksiężycowate często wyróżnia charakterystyczny retusz zębaty formowany na ich krawędziach wewnętrznych (Libera 2001, 59). Nawiązujące morfologią do sierpów - tzw. wkładki sierpowate, pod względem metrycznym niemal miniaturowe, nie są znane w zespołach wczesnej epoki brązu (por. Libera 2001, 99).

Należy zważyć na to, iż narzędzia krzemienne podlegały z całą pewnością różnego typu przeróbkom w zależności od potrzeb ich wytwórców i użytkowników (por. Budziszewski 1991, 193). Przykładem na to może być wielokrotnie przerabiany, krańcowo zużyty fragment bifacjalnej formy płoszczowatej z grobu $\mathrm{nr} 6 \mathrm{z}$ Miernowa (Kempisty 1978, ryc. 22:5 za Budziszewski 1991, 199). Ponadto wraz z morfologią mogła zmieniać się także funkcja tego narzędzia. Podobnie rzecz mogła się mieć w przypadku innych okazów z dwustronną obróbką powierzchniową. Bezkrytyczne uznawanie odkrywanych wyrobów krzemiennych jako pożądanych form, do których dążą jego wytwórcy może okazać się niesłuszne (por. Grace 1997). Warto także zwrócić uwagę na inną obserwację Libery. Otóż wiele sierpów wczesnobrązowych ma ostry, zaokrąglony lub ułamany wierzchołek (tzw. „noże sierpowate szeroko wierzchołkowe") (Libera 2001, 95). Zaokrąglenie jak i złamanie wierzchołka nie musi wszak wynikać z zamysłu wytwórcy narzędzia, ale z napraw i z intensywnego użytkowania.

Na wyroby bifacjalne warto chyba spojrzeć pod innym kątem, próbując udzielić odpowiedzi na pytanie o powody i reguły ich funkcjonowania w społeczeństwie. Jak zostało pokazane, narzędzia w typie płoszczy i sierpów są wyrobami wyraźnie odbiegającymi tech- 
nologicznie i surowcowo od powszechnych form odłupkowych znanych z Małopolski. Czy ta swoista dychotomia kształtu wytwórczości krzemieniarskiej może być odbiciem istnienia w obrębie społeczeństwa mierzanowickiego pewnych szczególnych norm zachowań w odniesieniu do technologii (por. Apel 2001)?

Szansę odpowiedzi daje koncepcja „łańcuchów operacji” (chaîne opératoire) (Pelegrain 1990) oraz teoria ulegania wpływom społecznym nakreślona przez Aronsona na gruncie psychologii społecznej (1997; ten sam 2009). W podejściu wymienionym jako pierwsze podkreślona jest rola sekwencji aktywności podejmowanych przez wytwórców narzędzi (Pelegrain 1990; Bar-Yosef, van Peer 2009). Koncepcja zakłada koniczność dostrzegania wszystkich możliwych procesów mających miejsce przy użytkowaniu surowca krzemiennego (Ryc. 8). Ten tzw. „łańcuch operacji” obejmuje poszczególne etapy związane z wykorzystaniem krzemienia przez dane społeczności - od momentu odkrycia surowca i jego pozyskania, poprzez selekcję, transport, obróbkę, użycie narzędzi, ewentualny recykling i reutylizację, aż do porzucenia artefaktów (m.in. Grace 1997). Teoria ta odnosi się do kontrolowanych strategii podejmowania decyzji na każdym z powyższej wymienionych etapów oraz do aktów („gestów”) technicznych, których poszczególne jednostki uczą się poprzez „zanurzenie” w kulturze. Dzięki temu podejściu bliższe staje zrozumienie różnorodności materiałów krzemiennych albo „odczytanie znaków” o decyzjach wytwórców i użytkowników narzędzi (Banning 2000, 141).

W rozumieniu tej koncepcji teoretycznej zabytki krzemienne należy postrzegać jako ślady ludzkich zachowań. Nie ulega wątpliwości, że produkcja narzędzi bifacjalnych jest procesem niezwykle złożonym. Nie ogranicza się ona do prostego powtarzania gestów technicznych. Na etapie obróbki należy krytycznie monitorować zaistniałe sytuacje (układ powstałych negatywów, kąty, krzywizny) oraz podejmować decyzje w zakresie zastosowania możliwie jak najlepszych rozwiązań technologicznych. Niezbędna jest wyobraźnia o produkcie. Wytwórca posiada w umyśle uporządkowaną sekwencję etapów zorganizowanych w konceptualny schemat operacji (por. Pelegrin, 116-125). Najprawdopodobniej umiejętności te mogli posiąść wyłącznie nieliczni. Przekonują o tym archeolodzy, którzy poświęcili wiele lat eksperymentom związanym z obróbką krzemienia (m.in. W. Migal i J. Pelegrin).

Całokształt wiedzy technologicznej obejmuje dwie zasadnicze części (Ryc. 9). Pierwszy z elementów to wiedza uświadomiona (knowledge). Etap ten określa jak radzić sobie z poszczególnymi sekwencjami procesu technologicznego (np. jakie narzędzia, zabiegi techniczne należy zastosować). Knowledge jest „komunikatywna”. Zachodzi między nauczycielem a uczniem poprzez obserwację i rozmowę (Pelegrin 1990, 118). Wiedzę tę należy postrzegać jako wyjaśnianie, komunikację oraz jako pamięć tylko teoretyczną - gdzie słowa są „dwuwymiarowe” (Apel 2001, ryc. 2.1., 28).

Składnik drugi to wiedza nieuświadomiona (know-how). Obejmuje ona uzyskiwanie umiejętności - naśladownictwo i uczenie się na zasadzie prób i błędów, a także nabywanie wiedzy, iż znajomość technologii zawsze jest powiązana z praktyką. Know-how jest jakby 
„nieprzytomna”. Budzi się ona w praktycznych doświadczeniach (Pelegrin 1990, 118). Ten rodzaj wiedzy wyrażany jest poprzez działanie, intuicję, nieświadomą pamięć - nieutraconą nawet w wypadku utraty pamięci. Nie są to już „dwuwymiarowe” słowa, ale pamięć obrazkowa (3D) (Apel 2001, ryc. 2.1., 28).

Samo przyswojenie wiedzy uświadomionej jest niewystarczające do produkcji zaawansowanych technologicznie narzędzi (np. płoszczy bifacjalnych). Taka produkcja wymaga zaawansowanego know-how, który może być osiągnięty tylko w oparciu o doświadczenie praktyczne (Apel 2001, 29). Konieczne jest, aby wytwórcy płoszczy i sierpów posiadali umiejętności perfekcyjnego łączenia wiedzy uświadomionej i nieuświadomionej oraz rozumieli, że oba aspekty są równie ważne (por. Schiffer, Skibo 1987, 597).

Zaprezentowana w artykule dwubiegunowość rozwoju krzemieniarstwa wczesnobrązowego w Małopolsce pozwala na wyciągnięcie określonych wniosków. Jak wspomniano powyżej wydaje się, że dostęp do znajomości technologii produkcji płoszczy i sierpów był bardzo ograniczony. Znajomość ich produkcji mogła leżeć w posiadaniu bardzo nielicznych grup specjalistów, być może całych wędrownych rodzin (por. uwagi Robinson et al. 2004, 150-151). Aby potrzymać tradycję wytwarzania narzędzi bifacjalnych przez stulecia musiały istnieć pewne systemy nauczania krzemieniarstwa i praktyk technologicznych (por. Apel 2001, 18-19). Pogląd ten warto odnieść do obserwacji i analiz innej technologii, także funkcjonującej wśród wczesnobrązowych społeczności w Małopolsce, mianowicie do produkcji paciorków fajansowych (Robinson et al. 2004). Robinson postrzega jej opanowanie jako relatywnie proste i osiągalne dla większości populacji mierzanowickiej (Robinson et al. 2004, 139). Aby produkować paciorki fajansowe, wystarczyło posiadać odpowiednie przygotowanie teoretyczne (knowledge) oraz zaplecze surowcowe (Robinson et al. 2004, 139). Odmiennie przedstawia się kwestia technologii produkcji płoszczy i sierpów. W tym przypadku, poza dostępnością odpowiedniej klasy surowca krzemiennego (por. Apel 2001, 30) i nabyciem wiedzy uświadomionej, niezwykle istotna była wiedza nieuświadomiona (know-how). Jej nabranie wiązało się zawsze z intensywnymi ćwiczeniami już od najmłodszych lat (,zanurzenie” w kulturze”) (Pelegrin 1990, 118).

Przytoczone dane pozwalają traktować obróbkę krzemienia jako część większego technologicznego systemu lub systemów przekazywanych z pokolenia na pokolenie (Banning 2000, 141). Zjawisko to wyjaśnia w pewien sposób psychologia społeczna. Wydaje się, iż jedność celów i sposobów postępowania wytwórców płoszczy i sierpów, podtrzymywane przez tradycję kulturową, sprzyjały ujawnieniu się zachowań konformistycznych wśród tej społeczności (Aronson et al. 1997, 278-296). Badacze zwracają uwagę, że do wdrażania technologii niezbędna była funkcja autorytetów-nauczycieli. Tylko funkcjonowanie tych konkretnych ról społecznych mogło skutecznie stymulować przekaz wiedzy technologicznej następnej generacji (Apel 2001, 30). Jak zatem wyglądała relacja pomiędzy nauczycielem a uczniem? Jak wiedza technologiczna mogła być przekazywana? Otóż mogło się to dziać pod wpływem określonych nacisków społecznych (Aronson et al. 1997). W relacji nauczyciel-uczeń zawsze pojawiają się dwa typy konformizmu - tzw. konformizm infor- 
macyjny i konformizm normatywny (Aronson et al. 1997, 299-306). Pierwszy z nich może ujawnić się w przypadku, gdy uczeń pobiera nauki technologiczne. Znajduje się on wówczas w sytuacji wcześniej nieznanej i ma trudność z wykształceniem zachowania pożądanego przez nauczyciela. Autorytet udziela uczniowi informacji, a ten z kolei powtarza wyuczone zachowanie w podobnych okolicznościach w przyszłości (Aronson et al. 1997; 268-269). Konformizm normatywny jest zwykle motywowany lękiem przed odrzuceniem przez grupę, bądź chęcią bycia przez nią zaakceptowanym. Autorytet stwarza w takich warunkach przekonanie o słuszności wykonywanych działań (Aronson et al. 1997, 278-279). Sam w sobie jest on wówczas wyznacznikiem dopuszczalnych norm. Stąd podporządkowanie się regułom stanowiącym o konieczności pobierania i krzewienia dalej nauk technologii. Konkludując powyższy wywód, naciski informacyjne i normatywne mogły powodować nasilony poziom posłuszeństwa (Aronson et al. 1997, 307). Wskutek tych praktyk uczniowie zyskiwali zarówno wiedzę uświadomioną, jak i nabywali trwałe umiejętności praktyczne. Wiedzę tę przekazywali oni następnemu pokoleniu krzemieniarzy.

Kolejnym czynnikiem zapewniającym trwałość i kilkusetletnią ciągłość omawianej tradycji krzemieniarskiej mogła być internalizacja norm społecznych. Grupy rzemieślników postępowały według wartości od dawna w nich zakorzenionych (Aronson et al. 1997, 287288). Ponadto wśród specjalistów presja podporządkowania się wywierana na jednostkę była o wiele większa niż w normalnych warunkach (Aronson et al. 1997, 290-299; por. także Newcomb et al. 1970, 508-514). Motyw dążenia do słuszności w obrębie tych grup był potężną i samo podtrzymującą się siłą, niezależną od stałego nadzoru, powiązanego z systemem kar i nagród. Postępujący bezrefleksyjny konformizm oddziaływał na grupy producentów płoszczy i sierpów w sposób tak znaczny, że poszczególne jednostki mechanicznie odwoływały się do określonych zachowań (Aronson et al. 1997, 287-289). Powyższe hipotezy mogą w pewien sposób przybliżać do odpowiedzi na pytanie o przyczyny zadziwiającej, kilkusetletniej ciągłości wytwarzania form bifacjalnych.

W świetle zaprezentowanego modelu teoretycznego, nie zaprzeczając jednocześnie utylitarnym funkcjom wyrobów bifacjalnych - potwierdzonym chociażby analizami mikroskopowymi Bąbla i Budziszewskiego (1978) oraz Balcera i Schilda (1980), winno się utrzymać hipotezę o ich głównie symbolicznym charakterze (por. m.in. Kadrow 1995a, 80). Należy przy tym zauważyć, iż producenci tych prestiżowych narzędzi wcale nie musieli być ich użytkownikami. Fenomen samego rozprzestrzenienia płoszczy i sierpów interpretować można jako wynik fizycznej migracji, być może następstwo funkcjonowania handlu lub wymiany albo też jako wyraz osobistych kontaktów z producentami na różnego typu ponadregionalnych uroczystościach. Pomimo stwierdzenia ewidentnej obecności płoszczy i sierpów wśród ludności mierzanowickiej mamy do czynienia z niemalże całkowitą absencją tych wytworów w kontekście osadowym. Uderza też znikoma ilość materiału produkcyjnego w postaci odłupków, utożsamianego z formowaniem tych narzędzi (por. Budziszewski 1991, 196). Występowanie tych form można rozumieć jako wyraz zapotrzebowania na wyroby prestiżowe związany z istnieniem we wczesnej epoce brązu w Małopolsce 
tzw. technologii prestiżowej (prestige technology; por. Olausson 2000, 128; Apel 2001, 330). Zaproponowanej hipotezy nie podważa nawet fakt przeważającej liczby przypadkowych znalezisk płoszczy i sierpów w stosunku do artefaktów tego typu wiązanych jednoznacznie z kontekstem sepulkralnym. Poddając pod rozwagę tę „przypadkowość” nie należy wykluczać specyficznej formy pochówku, która przy użyciu obecnych technik prospekcyjnych i wykopaliskowych nie jest rejestrowana (por. Balcer et al. 2002, 146; Libera 2010, 16).

\section{WNIOSKI KOŃCOWE}

Przedstawiona analiza krzemieniarstwa pozwala definiować gospodarkę surowcowo - narzędziową społeczności wczesnej epoki brązu z Małopolski jako samowystarczalną (Kopacz, Valde-Nowak 1987, 75; Kadrow 1995b, 241-245). Wytwarzania i użytkowania narzędzi o prostej, odłupkowej formie nie należy wiązać z wpływem panującej mody. Wytwórczość tę trzeba uznać raczej za dowód efektywności ekonomicznej (Kadrow 1995a, 78). Posiadanie narzędzi bifacjalnych w typie płoszczy i sierpów nie było warunkiem koniecznym do realizacji standardowych potrzeb gospodarczych (por. Kopacz, Valde-Nowak 1987, 76). Typowa społeczność wczesnobrązowa z Małopolski była w stanie obyć się zupełnie bez tych wytworów, co ilustrują liczne przykłady materiałów z osad (m.in. Iwanowice) (Kadrow 1995a, 80).

Zaprezentowane w artykule koncepcje teoretyczne narzucają wniosek, iż największa rola tradycji, rozumiana jako emocjonalna więź z przeszłością, ograniczona była przede wszystkim do produkcji płoszczy i sierpów. Zjawisko specjalizacji ich wytwórczości warunkowane było przez silny wpływ społeczny nauczycieli technologii, podtrzymujących system (lub systemy) nauk krzemieniarskich. Nie bez znaczenia pozostaje hipoteza o silnej internalizacji norm społecznych w odniesieniu do tradycji technologicznej.

Rozprzestrzenianie się płoszczy i sierpów nie było zapewne konsekwencją przepływu idei. Transmisja wiedzy technologicznej wąskimi kanałami w obrębie własnej grupy (lub grup) utrudniała dostęp do sekretu ich wytwarzania. W obliczu rozkwitającej specjalizacji produkcji w Europie wczesnej epoki brązu (Robinson et al. 2004, 150-151) uzasadnione wydaje się przyjęcie hipotezy o istnieniu w Małopolsce grup rzemieślników, być może całych rodzin-specjalistów o charakterze wędrownym, trudniących się technologią produkcji płoszczy i sierpów. W tym kontekście za słuszny należałoby przyjąć pogląd o ponadregionalnym i ponadkulturowym charakterze funkcjonowania narzędzi bifacjalnych w społeczeństwach wczesnobrązowych (por. uwagi Bargieł, Libera 2004, 180-184; Dzbyński 2008, 262). 


\section{ZAKOŃCZENIE}

Niniejszy artykuł należy traktować jako próbę ukazania ogólnej charakterystyki wczesnobrązowych inwentarzy krzemiennych z Małopolski. Zaproponowano ponadto model teoretyczny nawiązujący do kwestii specjalizacji produkcji oraz zapotrzebowania na wyroby prestiżowe wśród omawianych społeczności. Wierzę, że zaprezentowana problematyka stanie się przyczynkiem do dyskusji nad nowymi możliwościami badań krzemieniarstwa, ukierunkowanymi na interpretacje określonych zjawisk społecznych w pradziejach. Szansa taka wyłania się bez wątpienia na drodze interdyscyplinarnego dyskursu. W niniejszej pracy podjęto taką właśnie próbę. Wykorzystano przy tym ustalenia odnoszące się do wybranych modeli funkcjonowania społeczeństwa, znanych z kręgu nauk o człowieku.

Zdaję sobie sprawę, iż niektóre tezy zawarte w artykule mogą wydawać się kontrowersyjne, a przyjęcie ukazanej perspektywy badawczej trudne do zaakceptowania. Wiem, iż powyższe interpretacje winny znaleźć bardziej czytelne potwierdzenie w konkretnych materiałach archeologicznych. Stawiam sobie to za cel moich dalszych badań. 
